\title{
Nanodisperse gold catalysts in oxidation of benzyl alcohol: comparison of various supports under different conditions
}

\author{
Gergely Nagy, et al. [full author details at the end of the article]
}

Received: 15 April 2019 / Accepted: 2 June 2019 / Published online: 21 June 2019

(c) The Author(s) 2019

\begin{abstract}
Monodisperse gold particles (ca. $2 \mathrm{~nm}$ ) were prepared and deposited on various supports $\left(\mathrm{SiO}_{2}, \mathrm{Al}_{2} \mathrm{O}_{3}, \mathrm{HAP}, \mathrm{MgAl}_{2} \mathrm{O}_{4}\right.$ and $\left.\mathrm{MgO}\right)$. The acid/base properties of supports were characterized by $\mathrm{NH}_{3}$ and $\mathrm{CO}_{2}$ sorption. The size of the gold nanoparticles spans in the 1.7-6.5 nm mean diameter range after calcination as determined from TEM measurements. The amounts of accessible surface sites were estimated by binary concentration pulse chromatography of $\mathrm{CO}$ with $\mathrm{Kr}$ adsorption. The data are in agreement with the results of $\mathrm{CO}$ adsorption obtained by DRIFT spectroscopy. The activities of the catalysts were compared in the oxidation of benzyl alcohol in stirred batch reactors under two different conditions: in xylene solvent with atmospheric oxygen at $60{ }^{\circ} \mathrm{C}$ (in presence and in absence of $\mathrm{K}_{2} \mathrm{CO}_{3}$ ), and in a solvent-free mixture at elevated pressure and temperature $\left(5\right.$ bar $\left.\mathrm{O}_{2}, 150{ }^{\circ} \mathrm{C}, 5 \mathrm{~h}\right)$. The activities of catalysts in benzyl alcohol conversion are described in two variants, namely related to (i) active catalytic sites (ASNA), and (ii) number of $\mathrm{Au}$ atoms on the geometric surface of particles (GSNA). The activities of catalysts in xylene solvent at $60{ }^{\circ} \mathrm{C}$ were excellent, with $0.28-1.11 \mathrm{~s}^{-1}$ characteristic GSNA $_{\text {ini }}$ values (initial reaction rates related to surface $\mathrm{Au}$ atoms, $\mathrm{Au}_{\text {surf }}$ ) in presence of $\mathrm{K}_{2} \mathrm{CO}_{3}$. The observed order of activities under these conditions is $\mathrm{Au} / \mathrm{SiO}_{2}<\mathrm{Au} / \mathrm{Al}_{2} \mathrm{O}_{3}<\mathrm{Au} / \mathrm{HAP}<\mathrm{Au} / \mathrm{MgAl}_{2} \mathrm{O}_{4}<\mathrm{Au} / \mathrm{MgO}$. In the experiments performed at $150{ }^{\circ} \mathrm{C}$ under solvent-free conditions, the reaction partners are depleted in greater extents (with the exception of $\mathrm{Au} / \mathrm{Al}_{2} \mathrm{O}_{3}$ ), thus the obtained average $\mathrm{GSNA}_{\text {ave }}$ (average reaction rate during $5 \mathrm{~h}$ reaction related to $\mathrm{Au}_{\text {surf }}$ ) values are less reliable, however selectivity data provide useful information as well. These estimated average GSNA $_{\text {ave }}$ values $\left(0.14-0.83 \mathrm{~s}^{-1}\right)$ attest still good activities. For the interpretation of the obtained data, the roles of active sites on gold nanoparticles of various dispersion and the accessibility of their surfaces as well as the acid-base properties and surface hydroxyl concentration of supports, water ad- and desorption phenomena are considered simultaneously.
\end{abstract}

Electronic supplementary material The online version of this article (https://doi.org/10.1007/s1114 4-019-01615-8) contains supplementary material, which is available to authorized users. 
Keywords Benzyl alcohol oxidation - Supported gold catalysts - Distinction of active sites $\cdot$ Acid/base support effects $\cdot$ Binary concentration pulse chromatograohy

\section{Introduction}

Among wide catalytic applications of supported gold nanoparticles [1, 2], oxidation of benzyl alcohol $(\mathrm{BzOH})$ to benzaldehyde $(\mathrm{BzO})$ or to benzoic acid $(\mathrm{BzOOH})$ had also been in the focus of several studies. The reaction can be performed directly, by mixing the catalyst and the alcohol in the presence of oxygen, or in a reaction medium by using a solvent, which can either be an organic one, or water, and mixed, organic-aqueous media is applied often as well [3-5]. Furthermore, the addition of inorganic bases $\left(\mathrm{NaOH}, \mathrm{K}_{2} \mathrm{CO}_{3}\right.$, etc.) may significantly hinder the deactivation of catalyst $[6,7]$ and favours the formation of intermediate alcoholate [8]. In addition, it influences the selectivity and, in aqueous solution and under solvent-free conditions, promotes the formation of benzoic acid, in organic media benzyl benzoate $(\mathrm{BzOOBz})[4,7]$. The dehydrogenation of alcohols to aldehydes can also be performed under anaerobic conditions with similar supported gold catalysts [9]. The absence or presence and the participation of water is also crucial, it may contribute in different extents to the various elementary steps of the set of processes in the oxidation of $\mathrm{BzOH}[4,5,7,10]$.

The conversion of $\mathrm{BzOH}$ by oxidation may take place in various reactions $(\mathrm{A}-\mathrm{D}$, Scheme 1). First, the alcohol, $\mathrm{BzOH}$, can be oxidized to aldehyde, $\mathrm{BzO}$ (reaction A). The oxidation of $\mathrm{BzO}$ may proceed further in two directions. Namely, BzO may be converted to benzoic acid, $\mathrm{BzOOH}$ in reaction $\mathrm{B}$ and in a further step $\mathrm{BzOOBz}$ ester can be formed from $\mathrm{BzOOH}$ and from the starting $\mathrm{BzOH}$ (reaction $\mathrm{C}$ ). In another

Scheme 1 Various reaction paths in oxidation of benzyl alcohol (BzOH) (see [7])

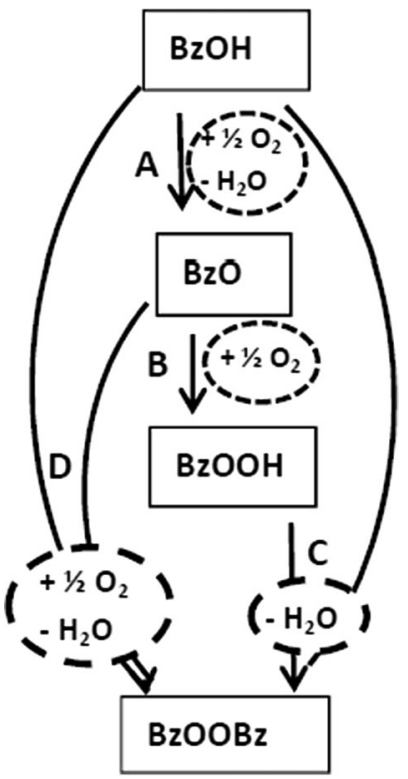


reaction, the formed aldehyde, $\mathrm{BzO}$ may also react with oxygen and with the original $\mathrm{BzOH}$ to form $\mathrm{BzOOBz}$ (reaction D) [7, 9, 11-13]. Further on, disproportionation reactions may also take place. Namely, from two $\mathrm{BzOH}$ molecules $\mathrm{BzO}$ and toluene $(\mathrm{BzH})$ may be formed [11], or, in other way, $\mathrm{BzOH}$ and benzoate anion may be formed from two aldehydes in presence of strong base (Cannizarro reaction).

The catalytic cycle of oxidation of $\mathrm{BzOH}$ in the process $\mathrm{A}$ is completed in three stages. First, the deprotonation of $\mathrm{BzOH}$ takes place by promotion of the basic $-\mathrm{OH}$ groups of the support or with $\mathrm{OH}^{-}$in the solution. The second step, the $\beta$-hydrogen elimination from the formed alkoxy intermediate proceeds on the metallic gold surface, the $\mathrm{BzO}$ product is formed in this stage. The cycle is closed in the third step by removing the bonded hydrogen from the gold surface in the reaction with oxygen or with $\mathrm{OH}^{-}[10]$ by forming water. Kinetic models were also constructed and verified for the description of the mentioned complete cycles of $\mathrm{BzOH}$ oxidation in $\mathrm{A}-\mathrm{D}$ reactions $[3,7,12,13]$.

The strong dependence of the turnover frequency related to surface $\mathrm{Au}$ atoms (TOF) on the size and shape of nanoparticles in $\mathrm{BzOH}$ oxidation is reported in [14]. A steep increase of TOF is reported on the decrease of particle size in $[9,15]$. The usage of the term TOF needs precaution, since TOF values strongly depend on the experimental conditions, and on the method by which they are deduced. In addition, they may change depending on the type of catalytic sites to which they are related [15-18]. For oxidation with gold nanoparticles, 6-9 nm optimal size is found in [19]. The simultaneous adsorption of oxygen strongly influences the performance: in the absence of oxygen, small particles are more active, whereas in the presence of $\mathrm{O}_{2}$, the larger ones exhibit better performance of ethanol oxidation [20]. CO probe molecule with Fourier transformed infrared spectroscopy (FTIR) detection is used preferably for the characterization of active sites on gold particles. The presence of apparent extra charges on metallic particles can also be identified from shifts of bands by in situ measurements [21]. The amount of the chemisorbed CO is also an important parameter, it can be determined quantitatively in equilibrium with gas phase by pulse and frontal chromatography methods [22, 23]. It is also worth mentioning that the modification of gold with a second alloying element may significantly increase the activity in oxidation processes (e.g., with Pd [12] or with $\mathrm{Ag}$ [24] and $\mathrm{Cu}$ [25]). An important factor in the reaction is the coverage of atomic oxygen on the metallic particles as well [26]. Adsorption of oxygen on gold particles can dominantly be observed in the $\sim 50-400{ }^{\circ} \mathrm{C}$ region [27].

The role of support is also crucial. It may participate in the sorption and $\mathrm{H}^{+}$ extraction processes $[28,29]$. The size and morphology of metallic particles also depend on the choice of support [1,30]. Furthermore, certain oxides may also directly supply oxygen for the oxidation (e.g., $\mathrm{CeO}_{2}$ ) [31, 32]. The basicity of the support is an advantageous feature, thus $\mathrm{MgO}$ is used in several cases [6, 28]. The binary, basic and acid features are even more favourable, as demonstrated with magnesium-aluminium hydrotalcite supports [9, 12, 29]. Other, less conventional oxide supports were also successfully applied in $\mathrm{BzOH}$ oxidation, e.g., zeolites [33], mixed $\mathrm{SiO}_{2}-\mathrm{Al}_{2} \mathrm{O}_{3}$ oxides (halloysite, [34]) or various $\mathrm{MgAl}_{2} \mathrm{O}_{4}$ spinels in oxidation of glycerol [35].

The catalytic cycles during the oxidation of $\mathrm{BzOH}$ in reactions $\mathrm{A}-\mathrm{D}$ are described in detail and are experimentally confirmed on $\mathrm{Au} / \mathrm{Al}_{2} \mathrm{O}_{3}$ in [7]. In the present study further 
conventional supports $\left(\mathrm{SiO}_{2}, \mathrm{MgO}\right.$ and $\left.\mathrm{MgAl}_{2} \mathrm{O}_{4}\right)$ beside $\mathrm{Al}_{2} \mathrm{O}_{3}$ are also compared in the oxidation of $\mathrm{BzOH}$. Hydroxyapatite (HAP) is also included since it exhibits reverse SMSI, namely, different extent of encapsulation of gold particles occurs by HAP upon oxidation [36]. The main emphasis is laid on studying the acid-base properties, thus redox supports $\left(\mathrm{CeO}_{2}, \mathrm{TiO}_{2}, \mathrm{~V}_{2} \mathrm{O}_{5}\right.$, etc.) are not involved. Two distant experimental conditions were selected. First, aerobic oxidation was carried out under mild conditions in xylene solvent at low-temperature $\left(60{ }^{\circ} \mathrm{C}\right)$ both in the presence and absence of $\mathrm{K}_{2} \mathrm{CO}_{3}$ additive. In the second series, solvent-free oxidation was accomplished under more severe conditions, in a closed autoclave by loading oxygen of 5 bar pressure at $150{ }^{\circ} \mathrm{C}$. Gold nanoparticles with uniform distribution $(\sim 1.9 \mathrm{~nm})$ were prepared with aqueous phase reduction and stabilization by polyvinyl alcohol, PVA [37, 38] then adsorbed on the mentioned supports, and activated by calcination in air. The distribution and mean sizes of gold particles were determined with TEM measurements. The surface properties of gold nanoparticles were probed by diffuse reflectance FTIR spectroscopy (DRIFTS) measurements in $\mathrm{CO}$ and in $\mathrm{CO}+\mathrm{O}_{2}$ mixtures. The accessibility and fractions of active surface sites are experimentally determined by a novel method, by binary concentration pulse chromatography of $\mathrm{CO}$ with $\mathrm{Kr}$ adsorption with fast quadrupole mass spectrometry (QMS) detection. Acid-base properties are evaluated with $\mathrm{CO}_{2}$ and $\mathrm{NH}_{3}$ adsorptions followed by temperature programmed desorption. The initial stages of $\mathrm{BzOH}$ oxidation processes were determined from the $60{ }^{\circ} \mathrm{C}$ measurements in xylene solvent and the activities are compared with the initial reaction rate method. The extents of conversions of $\mathrm{BzOH}$ and selectivities for $\mathrm{BzO}$ formation in solvent-free experiments performed at $150{ }^{\circ} \mathrm{C}$ for $5 \mathrm{~h}$ in a closed autoclave were also determined. The results are interpreted in comparison with those of the former $\left(60^{\circ} \mathrm{C}\right)$ series of measurements.

Emphasis is laid on the characterization and comparison of activity of gold on the different supports. Since the Au particle sizes vary in the samples compared, gold surface normalized activities are used (instead of the debated term of TOF [15-18]). Thus, conversion rates of $\mathrm{BzOH}$ are related to two types of accessible gold atoms. First, the activity is normalized to the total number of gold atoms present on the geometric surface of Au particles, geometric surface normalized activity, GSNA, is used. In the second variant, only the number of active sites enable to adsorb $\mathrm{CO}$ is considered, active site-normalized activity, ASNA, is applied. Initial conversion rates can reliably be derived from the initial period of reaction, when the extent of conversion is proportional to the time elapsed, these corresponding ASNA and GSNA values will be marked with "ini" subscript. Less exact activities which are deduced from a single conversion-time pair of values will be specified with "ave" (average) subscript.

\section{Experimental}

\section{Preparation of catalysts}

Samples were prepared by the adsorption of $\mathrm{Au}$ nanoparticles from $\mathrm{Au}$ sols on the different supports. Alumina, $\mathrm{Al}_{2} \mathrm{O}_{3}$ (Degussa Aluminium oxid C), silica, $\mathrm{SiO}_{2}$ (Aerosil A200), magnesia, $\mathrm{MgO}$ (Aldrich), magnesium aluminate, $\mathrm{MgAl}_{2} \mathrm{O}_{4}$ (Aldrich) 
non-porous nanopowders and hydroxyapatite $\left(\mathrm{Ca}_{10}\left(\mathrm{PO}_{4}\right)_{6}(\mathrm{OH})_{2}\right.$, HAP) were used for supporting Au nanoparticles. Specific surface area values were obtained from the suppliers (except HAP) and are shown in Table 1.

The preparation of HAP is described in [36], its specific surface area was determined with nitrogen physisorption measurements carried out at $77 \mathrm{~K}$ using a Thermo Scientific Surfer automatic, volumetric adsorption analyzer. Before adsorption analysis, the HAP sample was outgassed under vacuum for $2 \mathrm{~h}$ at $473 \mathrm{~K}$.

$\mathrm{Au}$ sols containing nanoparticles of c.a. $1.9 \mathrm{~nm}$ mean diameter were produced from the mixture of $37.5 \mathrm{ml} 6.0 \mathrm{mM} \mathrm{HAuCl}{ }_{4}, 45.0 \mathrm{ml} 0.2 \mathrm{wt} \%$ PVA solution and $600 \mathrm{ml}$ water by addition of $75 \mathrm{ml} 25 \mathrm{mM} \mathrm{NaBH}_{4}$ at about $0{ }^{\circ} \mathrm{C}$ [37].

$\mathrm{Au}$ sols in corresponding amounts were mixed with the supports to achieve the aimed Au loading. Appropriate amount of $0.08 \mathrm{wt} \%$ poly-diallyldimethylammonium chloride (PDDA) solution was also added to help the adsorption of metal particles (except in the case of alumina). The suspensions were stirred at room temperature for c.a. $2 \mathrm{~h}$. The colorless supernatant was removed by filtration, the solid was washed by water thoroughly, then dried overnight at $80{ }^{\circ} \mathrm{C}$. Catalysts were activated by calcination in air at $400{ }^{\circ} \mathrm{C}$ for $1 \mathrm{~h}$ removing the organic residues (PVA and PDDA) from the Au particles [39]. The gold loading of the catalysts was $3.0 \mathrm{wt} \%$ except $\mathrm{Au} / \mathrm{SiO}_{2}$ which contained $1.8 \mathrm{wt} \% \mathrm{Au}$.

\section{Sorption properties of supports: acid-base characteristics, density of surface $\mathrm{OH}$ groups}

The basic and acid properties were characterized by $\mathrm{CO}_{2}$ and $\mathrm{NH}_{3}$ TPD measurements, respectively, using an Autochem 2920 (Micromeritics) apparatus equipped with a QMS analyser (Thermostar, Pfeiffer Vacuum). For $\mathrm{CO}_{2}$ TPD measurements, $75 \mathrm{mg}$ of supports were conditioned at $150{ }^{\circ} \mathrm{C}$ in $\mathrm{Ar}$ for $30 \mathrm{~min}$, then the temperature was raised in $10{ }^{\circ} \mathrm{C} / \mathrm{min}$ ramp to $400{ }^{\circ} \mathrm{C}$ and kept for $10 \mathrm{~min} . \mathrm{CO}_{2}$ was adsorbed from $2 \% \mathrm{CO}_{2} / \mathrm{Ar}$ mixture at $40{ }^{\circ} \mathrm{C}$ for $30 \mathrm{~min}$, then the loosely adsorbed $\mathrm{CO}_{2}$ was removed in Ar flow at $40{ }^{\circ} \mathrm{C}$ for $60 \mathrm{~min}$. Temperature programmed desorption was performed by raising the temperature to $600{ }^{\circ} \mathrm{C}$, with $10{ }^{\circ} \mathrm{C} / \mathrm{min} \mathrm{ramp}$ in Ar stream $(30 \mathrm{ml} / \mathrm{min})$. Desorptions of $\mathrm{CO}_{2}(\mathrm{~m} / \mathrm{z}=44)$, and water $(\mathrm{m} / \mathrm{z}=18)$ were followed by QMS detection. The density of surface $\mathrm{OH}$ groups may also play role in the studied benzyl alcohol oxidation, thus the amount of the evolved water due to dehydroxylation was also monitored during the pretreatment of the supports.

For $\mathrm{NH}_{3}$ TPD measurements, $75 \mathrm{mg}$ of supports were conditioned at $150{ }^{\circ} \mathrm{C}$ in $\mathrm{He}$ for $30 \mathrm{~min}$, then the temperature was raised with $10{ }^{\circ} \mathrm{C} / \mathrm{min}$ ramp to $400{ }^{\circ} \mathrm{C}$ and kept for $10 \mathrm{~min} . \mathrm{NH}_{3}$ was adsorbed from $10 \% \mathrm{NH}_{3} / \mathrm{He}$ mixture at $40{ }^{\circ} \mathrm{C}$ for $30 \mathrm{~min}$ followed by removal of loosely adsorbed $\mathrm{NH}_{3}$ in $\mathrm{He}$ for $30 \mathrm{~min}$. The temperature programmed desorption of $\mathrm{NH}_{3}$ was performed with the raise of temperature of $10{ }^{\circ} \mathrm{C} / \mathrm{min}$ rate in $\mathrm{He}$ stream $(40 \mathrm{ml} / \mathrm{min})$. The amount of desorbed $\mathrm{NH}_{3}$ was determined with QMS as $\mathrm{NH}_{3}$ fragment $(\mathrm{m} / \mathrm{z}=16)$. 


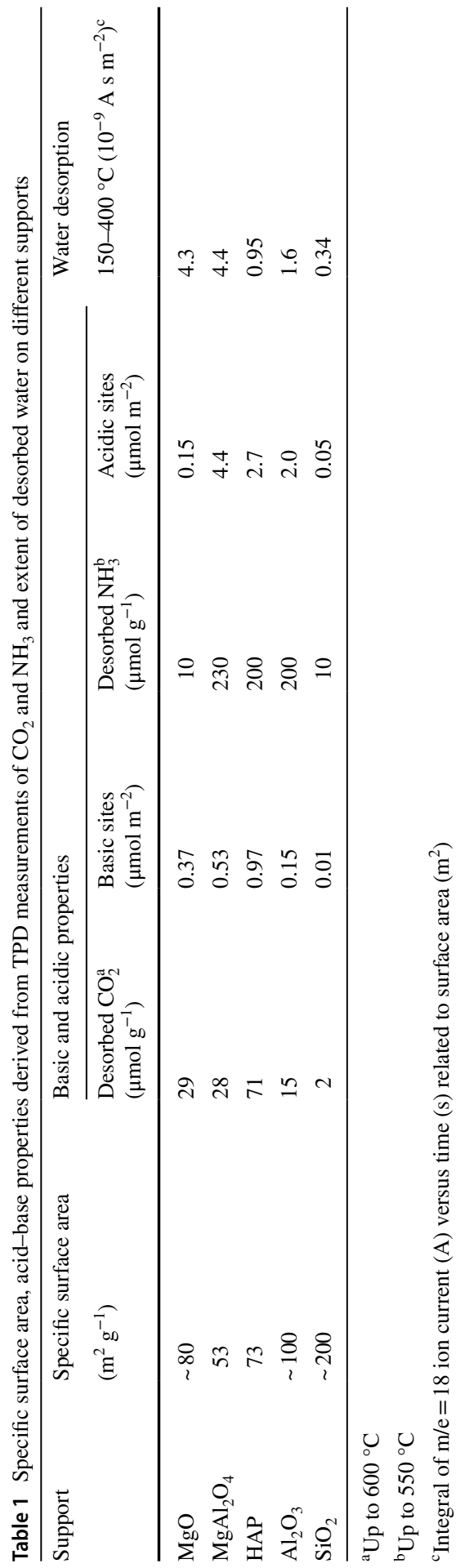




\section{Characterization of supported gold nanoparticles}

\section{Determination of particle size}

Gold particle size distributions in the calcined catalysts were determined by measuring diameters of c.a. 300 particles on each catalyst from images obtained with a JEOL 3010 electron microscope operating at $300 \mathrm{kV}$.

\section{CO adsorption followed by DRIFTS}

A Nicolet iS50 FTIR spectrometer equipped with a Specac diffuse reflection accessory and an in situ chamber was used for the measurements. Spectra of adsorbed $\mathrm{CO}$ were collected at $35{ }^{\circ} \mathrm{C}$ in three versions: (i) on the catalysts calcined ex situ at $400{ }^{\circ} \mathrm{C}$ and after two further consecutive in situ pretreatments, (ii) oxidation, $400{ }^{\circ} \mathrm{C} /$ air/10 min and (iii) reduction, $400{ }^{\circ} \mathrm{C} \mathrm{5 \%} \mathrm{H}_{2}$ in $\mathrm{Ar} / 30 \mathrm{~min}$. Spectra were recorded after the oxidation pretreatment following 5 min exposure to $1 \% \mathrm{CO}+1 \%$ $\mathrm{O}_{2} / \mathrm{He}$ gas flow, then also in $1 \% \mathrm{CO} / \mathrm{Ar}$, and after reduction, first in $1 \% \mathrm{CO} / \mathrm{Ar}$, then in $1 \% \mathrm{CO}+1 \% \mathrm{O}_{2} / \mathrm{He}$. The pretreatments were carried out in the flow of the specified treating gas mixture, the heating rate was $10{ }^{\circ} \mathrm{C} / \mathrm{min}$. The cooling after treatment in air was carried out in the same synthetic air, whereas after treatment in $5 \% \mathrm{H}_{2}$-Ar samples were cooled in Ar. Spectra recorded at $35^{\circ} \mathrm{C}$ after the pretreatment and prior the $\mathrm{CO}$ adsorption under Ar or air flow (in case of ex situ calcination or reduction pretreatments and oxidation, respectively) were used as reference for the $\log (1 / \mathrm{R})$ representations. From the spectra recorded during adsorption, the $\mathrm{CO}$ gas spectrum was eliminated by substraction. For comparison of the amounts of adsorbed $\mathrm{CO}$ the band intensities were considered, namely the integrals of $\log (1 / \mathrm{R})$ bands were determined.

\section{Determination of the amount of adsorbed CO with binary concentration pulse chromatography}

Binary concentration pulse method was applied since the conventional pulse chemisorption technique cannot be used due to the weak adsorption of $\mathrm{CO}$ on $\mathrm{Au}$. The amount of adsorbed $\mathrm{CO}$ from $1 \% \mathrm{CO}+1 \% \mathrm{Kr}$ in Ar pulse was determined with fast QMS (Thermostar) detection in an Autochem 2920 apparatus. Subsequent to the in situ calcination treatment $\left(400{ }^{\circ} \mathrm{C} / 10 \% \mathrm{O}_{2}\right.$ in $\mathrm{He} / 1 \mathrm{~h}$ followed by cooling in air) $75 \mathrm{mg}$ sample was exposed to $1 \% \mathrm{CO}$ at $35{ }^{\circ} \mathrm{C}$ by a fast switch of the pure Ar flow to a $1 \% \mathrm{CO}+1 \% \mathrm{Kr} / \mathrm{Ar}$ stream (both $10 \mathrm{ml} / \mathrm{min}$ flow rate). After equilibrating $\mathrm{CO}$ between the surface and the gas phase for $10 \mathrm{~min}$, the switch was reversed inducing the desorption of $\mathrm{CO}$. The $\mathrm{CO}$ signal of the effluent gas mixture is delayed in comparison to that of the inert, non-adsorbing $\mathrm{Kr}$ at the front side of the binary pulse due to adsorption of $\mathrm{CO}$. The area between the normalized $\mathrm{Kr}$ and $\mathrm{CO}$ signals is proportional to the amount of the adsorbed CO. In reverse, at the tail of the binary pulse the desorption of $\mathrm{CO}$ is delayed and the area between the normalized $\mathrm{Kr}$ and $\mathrm{CO}$ signals is proportional to the amount of the $\mathrm{CO}$ desorbed. Then, after $10 \mathrm{~min}$ on stream, the temperature was raised up to $400{ }^{\circ} \mathrm{C}$ by $10{ }^{\circ} \mathrm{C} / \mathrm{min}$ rate (CO-TPD) to 
complete the desorption. The amounts of adsorbed and desorbed $\mathrm{CO}$ were calculated by the difference between the integrals of the $\mathrm{CO}$ and $\mathrm{Kr}$ concentration versus time curves between the switch on and off time of $\mathrm{CO}+\mathrm{Kr} / \mathrm{Ar}$, and between the $\mathrm{CO}+\mathrm{Kr} / \mathrm{Ar}$ switch off and the end of TPD, respectively. The $\mathrm{CO}$ and $\mathrm{Kr}$ concentrations were calculated from the intensities of $\mathrm{m} / \mathrm{z}=28$ and 84 QMS signals.

The adsorption of $\mathrm{CO}$ on the bare supports is significantly smaller than on supported gold catalysts, but it is not negligible. Thus, amounts of adsorbed $\mathrm{CO}$ on pretreated supports were also determined and are taken into consideration at the corresponding calculations.

\section{Oxidation of $\mathrm{BzOH}$}

Experiments were carried out under two conditions:

(i) The aerobic oxidation of $\mathrm{BzOH}$ was performed in xylene solvent $(0.1 \mathrm{M}$ $\mathrm{BzOH})$ at $60{ }^{\circ} \mathrm{C}$ in a thermostated glass reactor with a magnetic stirrer and a reflux condenser. In a typical reaction $15 \mathrm{mg}$ calcined catalyst and $400 \mathrm{mg}$ $\mathrm{K}_{2} \mathrm{CO}_{3}$ was added to a mixture of $29.4 \mathrm{ml}$ xylene and $0.3 \mathrm{ml}$ dodecane as internal reference (in the case of $\mathrm{Au} / \mathrm{SiO}_{2}, 25 \mathrm{mg}$ catalyst was used to attain the same substrate/metal ratio). $\mathrm{K}_{2} \mathrm{CO}_{3}$ was used to prevent deactivation caused by benzoic acid poisoning (benzoic acid is possible trace contamination of benzyl alcohol and is the product of the reaction in further stages, too). The reaction was performed also without addition of base using the same reaction conditions in another series. The suspension was heated to $60{ }^{\circ} \mathrm{C}$ under stirring $(1350 \mathrm{rpm})$, then $\mathrm{O}_{2}$ was bubbled through the suspension with a flow rate of $150 \mathrm{ml} / \mathrm{min}(1 \mathrm{~atm})$. After $20 \mathrm{~min}$ the reaction was started by adding $0.3 \mathrm{ml}$ ( $2.9 \mathrm{mmol}$ ) benzyl alcohol (providing a substrate/metal molar ratio of $\sim 1300$ ). For analysing the reaction mixture $\sim 0.2 \mathrm{ml}$ samples were withdrawn with a syringe during the reaction in $10 \mathrm{~min}$ intervals. After the filtration of the catalyst and $\mathrm{K}_{2} \mathrm{CO}_{3}$ the liquid was analyzed by a CHROMPACK CP 9000 type gas chromatograph (GC) equipped with a FID detector using a CP-Sil5-CB $(50.0 \mathrm{~m} \times 0.32 \mathrm{~mm} \times 1.19 \mu \mathrm{m})$ capillary column. Beside benzaldehyde, only benzyl benzoate was detected as byproduct. The initial reaction rate was calculated from the first three points of the conversion curves (up to $30 \mathrm{~min}$ reaction time, linear region). $\mathrm{GSNA}_{\text {ini }}$ and $\mathrm{ASNA}_{\text {ini }}$ values were determined by dividing the initial reaction rate of $\mathrm{BzOH}$ conversion with molar amount of $\mathrm{Au}$ atoms located on the geometric surface of particles, and with molar amount of surface $\mathrm{Au}$ atoms able to adsorb $\mathrm{CO}$ molecules, respectively.

(ii) Solvent-free oxidations were carried out in an autoclave equipped with a magnetic stirrer. In a typical procedure, $50 \mathrm{mg}$ catalyst and $2 \mathrm{ml} \mathrm{BzOH}$ (corresponding to substrate/metal $\sim 2500$ molar ratio) were placed to the autoclave which was then flushed with 5 bar $\mathrm{O}_{2}$ for five times, and loaded finally with 5 bar $\mathrm{O}_{2}$. The autoclave was closed, then it was heated to $150{ }^{\circ} \mathrm{C}$ and kept for $5 \mathrm{~h}$ afterwards. The reaction was stopped by cooling the autoclave, then $0.05 \mathrm{ml}$ dodecane as inner standard was added to $0.1 \mathrm{ml}$ of the filtered reaction liquid and the mixture was diluted with $1 \mathrm{ml}$ ethyl acetate. The 
products were analyzed by gas chromatography-mass spectrometry (GCMS) tandem, an Agilent 7890B instrument equipped with an on-column injector $\left(260{ }^{\circ} \mathrm{C}\right)$, a FID detector $\left(325^{\circ} \mathrm{C}\right)$ and an HP-5 capillary column $(30 \mathrm{~m} \times 0.32 \mathrm{~mm} \times 0.25 \mathrm{~mm})$. Conversions and selectivities were calculated from these data. The average reaction rates during $5 \mathrm{~h}$ reaction were determined from conversions, from that average GSNA ave values were calculated.

\section{Results and discussion}

\section{Acid-base properties of the supports}

The acid-base properties of the supports were evaluated with $\mathrm{CO}_{2}$ and $\mathrm{NH}_{3}$ adsorption followed by TPD measurements (Fig. 1). Total amounts of $\mathrm{CO}_{2}$ and $\mathrm{NH}_{3}$ desorbed up to $600{ }^{\circ} \mathrm{C}$ and $550{ }^{\circ} \mathrm{C}$, respectively, are shown in Table 1 .

The characteristics of the various supports are rather different from the aspect of basicity. In the literature, the basicities of oxides are classified in three groups concerning the strength of base sites. The weak sites are related to surface hydroxyl groups, the medium ones to $\mathrm{M}^{\mathrm{n}+}-\mathrm{O}^{2-}$ pairs, the strong ones to low coordination $\mathrm{O}^{2-}$ ions [40]. $\mathrm{SiO}_{2}$ hardly exhibits any adsorption/desorption of $\mathrm{CO}_{2}$. The basicity of alumina is also weak, most of desorption has taken place below $150{ }^{\circ} \mathrm{C}$, the amount of evolved $\mathrm{CO}_{2}$ is small. The sorption of $\mathrm{CO}_{2}$ and basic strength on $\mathrm{MgO}$ is more expressed. It is worth noticing that the evolution of $\mathrm{CO}_{2}$ proceeds in three steps. The first two of them appear in two overlapping peaks with a maximum of desorption around $140{ }^{\circ} \mathrm{C}$, and a shoulder around $100{ }^{\circ} \mathrm{C}$. A smaller desorption peak appears around $450{ }^{\circ} \mathrm{C}$ as well. It can be supposed that $\mathrm{CO}_{2}$ released around $100{ }^{\circ} \mathrm{C}$ originates from carbon dioxide attached to the $-\mathrm{OH}$ groups forming bicarbonate, whereas the $\mathrm{CO}_{2}$ evolution between $140-400{ }^{\circ} \mathrm{C}$ and above $400{ }^{\circ} \mathrm{C}$ is related to decomposition of bidentate and the more stable unidentate carbonates, bonded to $\mathrm{Mg}^{2+}-\mathrm{O}^{2-}$ pair sites and isolated $\mathrm{O}^{2-}$ ions on surface edges or corners [41]. A similar amount
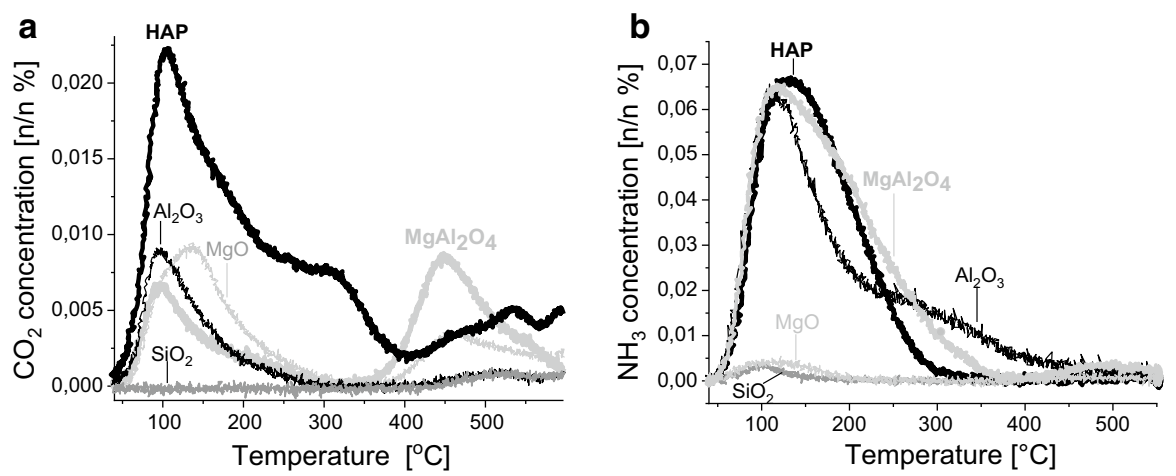

Fig. 1 Acid-base properties of the supports: $\mathrm{CO}_{2}$-TPD for basicity (a, left), $\mathrm{NH}_{3}$-TPD for acidity (b, right) characterization 
of $\mathrm{CO}_{2}$ is desorbed from $\mathrm{MgAl}_{2} \mathrm{O}_{4}$, reflecting a higher surface density, and its larger part is related to stronger basic sites with desorption around $450{ }^{\circ} \mathrm{C}$. The basicity of $\mathrm{HAP}$ is the highest among the studied supports. The dominant part of $\mathrm{CO}_{2}$ is evolved around $120{ }^{\circ} \mathrm{C}$ and a significant part is still originated from stronger basic sites with release around $300{ }^{\circ} \mathrm{C}$ and above $400{ }^{\circ} \mathrm{C}$. Without distinction of strengths, the overall specific basicities are in the order $\mathrm{SiO}_{2}<\mathrm{Al}_{2} \mathrm{O}_{3}<\mathrm{MgO} \approx \mathrm{MgAl}_{2} \mathrm{O}_{4}<\mathrm{HAP}$ (Table 1).

The acidities of various supports are also characteristically different (Fig. 1b). The adsorption of ammonia on magnesia and silica is negligible. Acidities of $\mathrm{MgAl}_{2} \mathrm{O}_{4}$, $\mathrm{HAP}$ and $\mathrm{Al}_{2} \mathrm{O}_{3}$ are more expressed. The desorption of $\mathrm{NH}_{3}$ results in broad peaks for $\mathrm{MgAl}_{2} \mathrm{O}_{4}$ and $\mathrm{HAP}$, whereas the strengths of acidic sites were distinctly different on alumina, the presence of weaker sites is reflected in a low temperature peak centered around $120{ }^{\circ} \mathrm{C}$, stronger sites result in a broader $200-350{ }^{\circ} \mathrm{C}$ desorption. Similar $\mathrm{NH}_{3}$ desorption patterns are reported for catalysts on these supports e.g., in [9]. Specific acidity data are shown in Table 1.

\section{Sorption/desorption of water, density of surface hydroxyls}

The desorption of water from the supports was also traced in our study, since presence of water and hydroxyl groups may significantly accelerate the processes of $\mathrm{BzOH}$ oxidation and water is formed itself in the reaction. The signal of desorbed water $(\mathrm{m} / \mathrm{z}=18)$ was traced by QMS detection of the TPD in Ar between 150 and $400{ }^{\circ} \mathrm{C}$, subsequently to $30 \mathrm{~min}$ pretreatment in $\mathrm{Ar}$ at $150{ }^{\circ} \mathrm{C}$. The signal originates primarily from surface $\mathrm{OH}$ groups since the physisorbed water is removed with the applied pretreatment (Fig. 2). Integrated amounts of $\mathrm{m} / \mathrm{e}=18$ signal versus time in the $150-400{ }^{\circ} \mathrm{C}$ region of the curves in Fig. 2 are collected in Table 1 as well. Thus, an indication on the amounts of the surface density of hydroxyls on the various supports can be obtained and compared.

The largest evolved amount of water is obtained from $\mathrm{MgO}$ support. Only a small amount appears in the $200-250{ }^{\circ} \mathrm{C}$ range, characteristic otherwise for the dominant desorption on $\mathrm{MgAl}_{2} \mathrm{O}_{4}$ and $\mathrm{Al}_{2} \mathrm{O}_{3}$. The overwhelming desorption takes

Fig. 2 Desorption of water from different supports $(\mathrm{m} / \mathrm{z}=18$ QMS signal), during pretreatment in $\mathrm{Ar}$ in the $150-400^{\circ} \mathrm{C}$ range

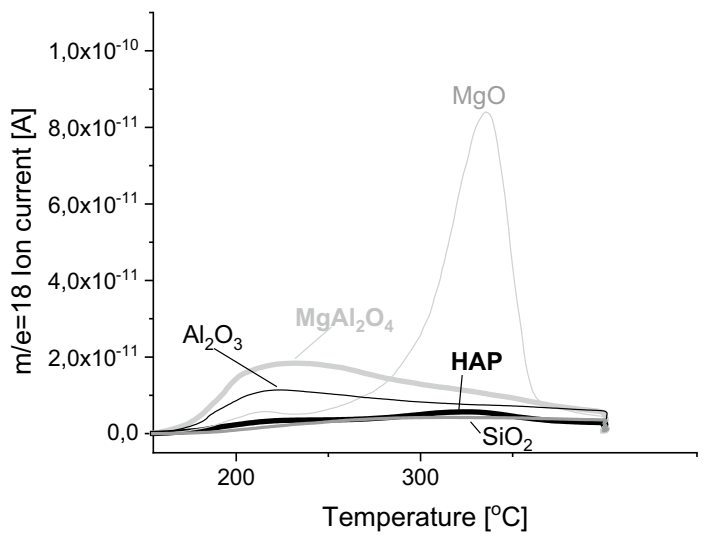


place at $300-350{ }^{\circ} \mathrm{C}$, in a typical temperature range observed for $\mathrm{Mg}(\mathrm{OH})_{2} \rightarrow \mathrm{MgO}$ conversion on small particles [42] (Fig. 2). Thus, $\mathrm{OH}$ groups on $\mathrm{MgO}$ are probably bonded more strongly. On HAP and $\mathrm{SiO}_{2}$ the water evolution is negligible compared to the other supports. The amounts of the evolved water related to unit surface area can also be estimated on the different supports (Table 1). The density of surface $\mathrm{OH}$ groups decreased on the various supports in the following order: $\mathrm{MgAl}_{2} \mathrm{O}_{4} \approx \mathrm{MgO}>\mathrm{Al}_{2} \mathrm{O}_{3}>\mathrm{HAP}>\mathrm{SiO}_{2}$. In a consecutive TPD from 400 to $800{ }^{\circ} \mathrm{C}$, an additional, but significantly lower amount of water evolved (not shown) due to further dehydroxylation. However, considering the sum of hydroxyl eliminated between 150 and $800{ }^{\circ} \mathrm{C}$, the order of supports does not change.

\section{Particle size distributions, average particle sizes, dispersions}

From TEM images (representative ones are shown in the Fig. 3) the gold particle size distributions (Fig. 3, insets) of the calcined $\left(400{ }^{\circ} \mathrm{C} / \mathrm{air} / 1 \mathrm{~h}\right)$ catalysts were determined. The mean particle diameter $\left(d_{m}\right)$ was calculated by using the $d_{m}=\sum d_{i} n_{i} / \sum n_{i}$ formula where $n_{i}$ is the number of particles of diameter $d_{i}$ (Table 2). Dispersions were also estimated with geometrical approximation (similarly to [3, 14, 19]). Spherical shape was assumed for the gold particles, and for the estimation of the number of surface gold atoms 11.5 gold atom per unit area $\left(\mathrm{nm}^{-2}\right)$ surface density value was applied [43]. In accordance, the dispersion (D) of gold was calculated by the $D=1.17\left(\sum d_{i}^{2} n_{i} / \sum n_{i}\right) /\left(\sum d_{i}^{3} n_{i} / \sum n_{i}\right)$ formula, where $d$ is expressed in nm. It is worth noticing that the original small size of the gold nanoparticles is preserved only on the $\mathrm{Al}_{2} \mathrm{O}_{3}$ support. Certain agglomeration has taken place during the $400{ }^{\circ} \mathrm{C}$ calcination on all the other supports, particularly on $\mathrm{MgO}$. It is worth noticing that the crystal shape of stable gold nanoparticles varies with the size [44]. However, the influence of this effect is neglected in our evaluation.

\section{CO adsorption (DRIFTS)}

Concentration and properties of the low coordinated Au sites, generally the most reactive ones can be characterized by comparing the adsorption of $\mathrm{CO}$ on various catalysts as reflected in DRIFT spectra. As for the effect of particle size in the oxidation of alcohols, the reports are controversial. There are publications suggesting the steep increase of TOF with decreasing gold particle size [9, 14, 15], in contrast, a volcano shape size dependence is also reported with TOF maximum at around 6-9 nm particle size in [19].

The redox steps of $\beta$-hydride elimination and the removal of the separated hydrogen with oxygen in a subsequent stage on the surface of gold nanoparticles is crucial in the catalytic cycle of $\mathrm{BzOH}$ oxidation. Thus, the effects of redox pretreatments on the supported gold nanoparticles were monitored by measuring the $\mathrm{CO}$ sorption under two conditions at room temperature. First, the co-adsorption of $\mathrm{CO}$ and oxygen was performed from $1 \% \mathrm{CO}+1 \% \mathrm{O}_{2} / \mathrm{He}$ mixture on the ex situ calcined sample and on samples exposed to in situ oxidizing pretreatments. Second, CO sorption from $1 \% \mathrm{CO} / \mathrm{Ar}$ mixture was measured. After the in situ reducing pretreatment, the 

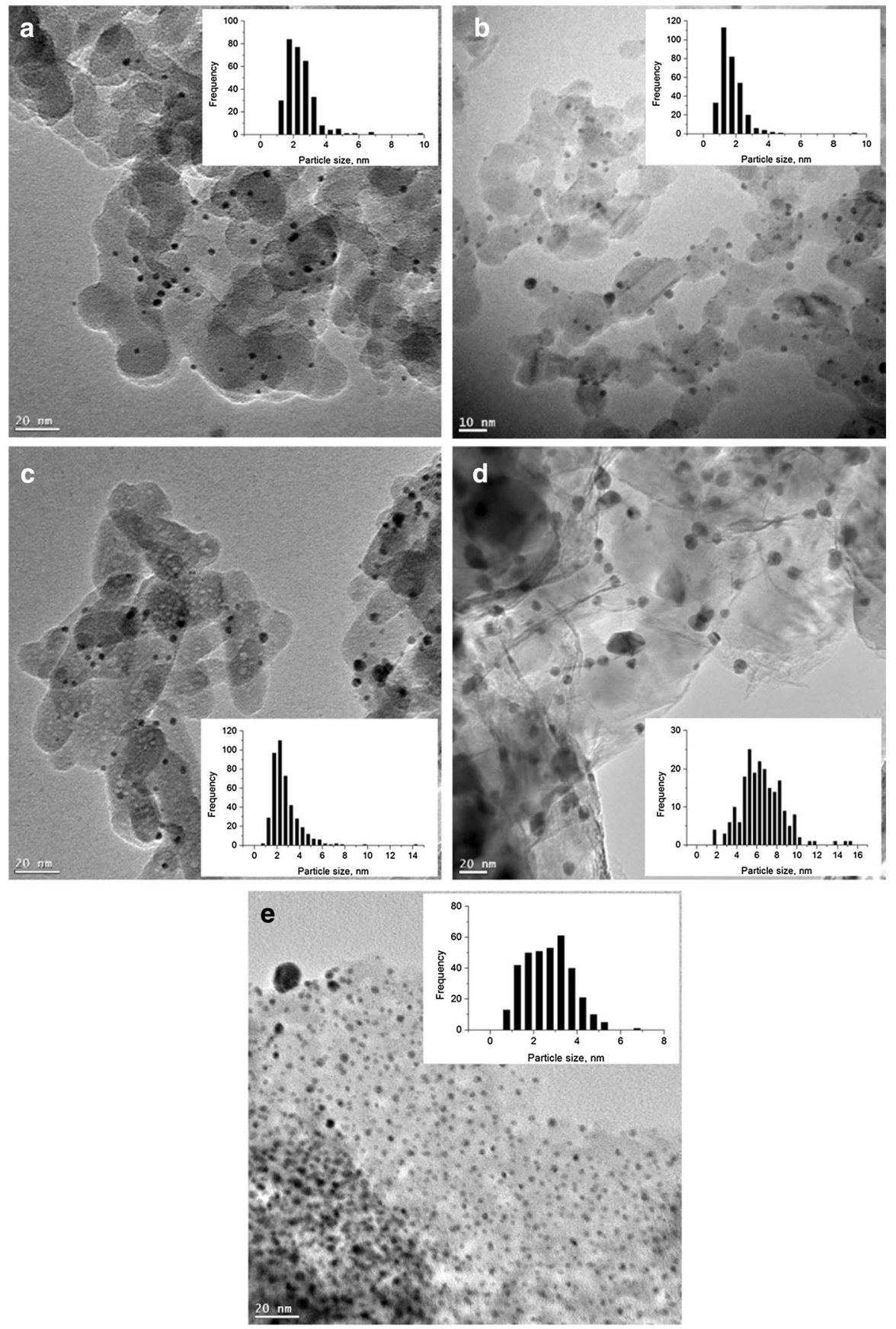

Fig. 3 Representative TEM images of the various calcined catalysts. a $\mathrm{Au} / \mathrm{SiO}_{2}, \mathbf{b} \mathrm{Au} / \mathrm{Al}_{2} \mathrm{O}_{3}, \mathbf{c} \mathrm{Au} / \mathrm{HAP}$, d $\mathrm{Au} / \mathrm{MgO}$, e Au/ $\mathrm{MgAl}_{2} \mathrm{O}_{4}$. The corresponding particle size distributions are shown in the insets 
Table 2 Mean diameter and dispersion values of Au particles on various supports

\begin{tabular}{llllll}
\hline & $\mathrm{Au} / \mathrm{SiO}_{2}$ & $\mathrm{Au} / \mathrm{Al}_{2} \mathrm{O}_{3}$ & $\mathrm{Au} / \mathrm{HAP}$ & $\mathrm{Au} / \mathrm{MgAl}_{2} \mathrm{O}_{4}$ & $\mathrm{Au} / \mathrm{MgO}$ \\
\hline Au loading (wt\%) & 1.8 & 3.0 & 3.0 & 3.0 & 3.0 \\
Mean diameter (nm) & 2.4 & 1.7 & 2.7 & 2.7 & 6.5 \\
Dispersion (\%) & 35 & 43 & 27 & 34 & 15 \\
\hline
\end{tabular}

sorption of $\mathrm{CO}$ alone preceded the co-adsorption of $\mathrm{CO}+\mathrm{O}_{2}$. Special attention was devoted to monitoring the blue shift occurring in the band of carbon monoxide coadsorbed with $\mathrm{O}_{2}$. The results are summarized in Table 3, corresponding spectra are shown in Fig. S1 (Supplementary Material).

In general, blue shift (increase of wave number) appears when oxidized samples are compared to reduced metallic ones [21, 45, 46]. Another similar process, the coadsorption of $\mathrm{CO}$ and $\mathrm{O}_{2}$ on metallic gold may also result in certain blue shift. The blue shift is an indication of the appearance of a certain electron deficiency (partial positive charge) on the particles. This positive charge may influence the reactivity of particles [47]. In the evaluation of the observed band shifts, the red shift induced by the increase of $\mathrm{CO}$ surface coverage typical on gold also must be taken into consideration. The effect of the co-adsorption of $\mathrm{O}_{2}$ with $\mathrm{CO}$ on the $\mathrm{CO}$ band position can be observed reliably on the reduced samples. The increase of the extent of this phenomenon is in the $\mathrm{Au} / \mathrm{SiO}_{2}<\mathrm{Au} / \mathrm{MgAl}_{2} \mathrm{O}_{4}<\mathrm{Au} / \mathrm{Al}_{2} \mathrm{O}_{3}<\mathrm{Au} / \mathrm{MgO}<\mathrm{Au} / \mathrm{HAP}$ order. The differences in the sizes of gold nanoparticles on the various supports (Table 2) may influence the density of the coordinatively unsaturated gold sites on which coadsorption of $\mathrm{CO}$ and $\mathrm{O}_{2}$ is taking place. Furthermore, it is also worth considering that the size of Au particles on $\mathrm{MgO}$ is the largest however, a significant blue shift is still observed.

It is worth emphasizing that the $\mathrm{BzOH}$ oxidation reaction was performed with catalysts activated by calcination previously, i.e., on gold particles with partly oxidized surfaces. This is shown by the appearance of a larger frequency band (2123-2126 $\mathrm{cm}^{-1}$ ) with decreasing intensity ratio on $\mathrm{Au}$ supported on $\mathrm{SiO}_{2}$,

Table 3 Wavenumbers of CO band maxima in DRIFT spectra of adsorbed CO at room temperature after various pretreatments of supported gold catalysts

\begin{tabular}{|c|c|c|c|c|c|c|}
\hline \multirow{2}{*}{$\begin{array}{l}\text { Treatment } \\
\left(400^{\circ} \mathrm{C}\right)\end{array}$} & \multirow[t]{2}{*}{ Probe gas } & \multicolumn{5}{|c|}{ Wavenumbers of $\mathrm{CO}$ band maxima $\left(\mathrm{cm}^{-1}\right)$} \\
\hline & & $\mathrm{Au} / \mathrm{SiO}_{2}$ & $\mathrm{Au} / \mathrm{Al}_{2} \mathrm{O}_{3}$ & $\mathrm{Au} / \mathrm{HAP}$ & $\mathrm{Au} / \mathrm{MgAl}_{2} \mathrm{O}_{4}$ & $\mathrm{Au} / \mathrm{MgO}$ \\
\hline Air/ex situ & \multirow[t]{3}{*}{$1 \% \mathrm{CO}$ in $\mathrm{Ar}$} & $2110,2126 \mathrm{sh}$ & $2102,2123 \mathrm{vw} \mathrm{sh}$ & 2108 & 2106 & 2102 \\
\hline Air/in situ & & $2115,2126 \mathrm{sh}$ & $2107,2123 \mathrm{vw}$ sh & 2111 & $2110,2123 \mathrm{sh}$ & 2105 \\
\hline $5 \% \mathrm{H}_{2} / \mathrm{Ar}$ & & 2109 & 2105 & 2108 & 2107 & 2104 \\
\hline Air/ex situ & \multirow{3}{*}{$\begin{array}{l}1 \% \mathrm{CO}+1 \% \mathrm{O}_{2} \\
\text { in } \mathrm{He}\end{array}$} & 2126,2112 & $2106,2123 \mathrm{w} \mathrm{sh}$ & 2120 & $2110,2123 \mathrm{sh}$ & 2105 \\
\hline Air/in situ & & $2126,2113 \mathrm{sh}$ & $2112,2123 \mathrm{w} \mathrm{sh}$ & 2120 & $2123,2111 \mathrm{w} \mathrm{sh}$ & 2110 \\
\hline $5 \% \mathrm{H}_{2} / \mathrm{Ar}$ & & 2112 & 2110 & 2116 & 2110 & 2110 \\
\hline
\end{tabular}

$s h$ shoulder, $w$ sh weak shoulder, $v w$ sh very weak shoulder 
$\mathrm{MgAl}_{2} \mathrm{O}_{4}$ and $\mathrm{Al}_{2} \mathrm{O}_{3}$ overlapping with the band assigned to the $\mathrm{CO}$ co-adsorbed with $\mathrm{O}_{2}$ on metallic Au sites $\left(2110-2113 \mathrm{~cm}^{-1}\right)$. On Au/HAP, the simultaneous presence of this two $\mathrm{CO}$ bands cannot be recognized, but a small blue shift $\left(4 \mathrm{~cm}^{-1}\right)$ compared to the band of the co-adsorbed $\mathrm{CO}+\mathrm{O}_{2}$ on the reduced sample can be observed. In the case of $\mathrm{Au} / \mathrm{MgO}$, no significant difference can be observed between the CO-band positions recorded on the in situ calcined and reduced state.

On another aspect, the intensities of $\mathrm{CO}_{\text {ads }}$ bands are distinctly different on the various catalysts (Fig. S1). These intensities can be correlated to the amounts of adsorbed CO, a comparison of them is presented in Table 4. The order of them on catalysts with the corresponding supports is $\mathrm{Al}_{2} \mathrm{O}_{3}>\mathrm{SiO}_{2} \approx \mathrm{MgAl}_{2} \mathrm{O}_{4}>\mathrm{HAP}>\mathrm{MgO}$. That is in good correlation with the particle sizes, except Au/HAP on that the CO band intensities are smaller than expected. There is one order of magnitude difference between the highest and smallest peak areas $\left(\mathrm{Al}_{2} \mathrm{O}_{3}\right.$ and $\mathrm{MgO}$, respectivelyTable 4). The reduction/oxidation pretreatment has only a minor influence on the $\mathrm{CO}$ band intensities, in particular, the reductive pretreatment results in some decrease of the $\mathrm{CO}$ bands on $\mathrm{Au} / \mathrm{HAP}$, and larger on $\mathrm{Au} / \mathrm{MgO}$ that might be due to some further sintering. $\mathrm{Au} / \mathrm{Al}_{2} \mathrm{O}_{3}$ is the outermost as for the amount of adsorbed $\mathrm{CO}$. The blue shift is the smallest on $\mathrm{Au} / \mathrm{MgO}$ after oxidation, while on Au/HAP is the largest on the $\mathrm{O}_{2}$ co-adsorption with $\mathrm{CO}$ (Table 3).

\section{Determination of the amount of adsorbed CO from binary concentration pulse chromatography}

DRIFTS CO measurements do not provide exact information on the amounts of the adsorbed CO. A more accurate technique, the binary concentration pulse chromatography with fast mass spectrometric detection can be applied for quantitative measurements. The method is demonstrated in Fig. $4 \mathrm{a}$ in the case of $\mathrm{Au} / \mathrm{Al}_{2} \mathrm{O}_{3}$ catalyst. The Ar flow through the catalyst was changed instantly to $1 \% \mathrm{CO}+1 \%$

Table 4 Amounts of CO adsorbed on gold calculated from intensities of DRIFTS bands (2150$2050 \mathrm{~cm}^{-1}$ ) and amounts of adsorbed and desorbed CO from gold determined by binary concentration pulse chromatography and the derived partial coverage of the surfaces of gold nanoparticles in the various calcined samples

\begin{tabular}{|c|c|c|c|c|}
\hline & $\begin{array}{l}\text { DRIFTS } \mathrm{CO}_{\text {ads }} \text { band } \\
\text { intensity }\end{array}$ & $\begin{array}{l}\mathrm{CO}_{\text {ads }} \mathrm{mol} \mathrm{CO} / \\
\text { mol Au }\end{array}$ & $\begin{array}{l}\mathrm{CO}_{\mathrm{des}} \mathrm{mol} \mathrm{CO} / \\
\mathrm{mol} \mathrm{Au}\end{array}$ & $\begin{array}{l}\mathrm{CO}_{\mathrm{des}} \mathrm{mol} \\
\mathrm{CO} / \mathrm{mol} \\
\mathrm{Au}_{\text {surf }}^{\mathrm{a}}\end{array}$ \\
\hline $\mathrm{Au} / \mathrm{SiO}_{2}$ & $6.5^{\mathrm{b}}$ & 0.020 & 0.026 & 0.07 \\
\hline $\mathrm{Au} / \mathrm{Al}_{2} \mathrm{O}_{3}$ & 12.2 & 0.153 & 0.066 & 0.15 \\
\hline $\mathrm{Au} / \mathrm{HAP}$ & 2.0 & 0.018 & 0.009 & 0.03 \\
\hline $\mathrm{Au} / \mathrm{MgAl}_{2} \mathrm{O}_{4}$ & 5.0 & 0.052 & 0.027 & 0.08 \\
\hline $\mathrm{Au} / \mathrm{MgO}$ & 1.3 & 0.006 & 0.004 & 0.03 \\
\hline
\end{tabular}

${ }^{\mathrm{a}} \mathrm{Au}_{\text {surf }}$ is calculated by the multiplication of gold concentration of the samples $\left(\mathrm{mol} / \mathrm{g}_{\text {cat }}\right)$ by the dispersion data calculated from the particle diameters (Table 2)

${ }^{\mathrm{b}} \mathrm{The}$ band intensities measured on the $1.8 \mathrm{wt} \% \mathrm{Au} / \mathrm{SiO}_{2}$ were normalized to $3 \mathrm{wt} \%$ Au content for better comparisons with the other catalysts 
a

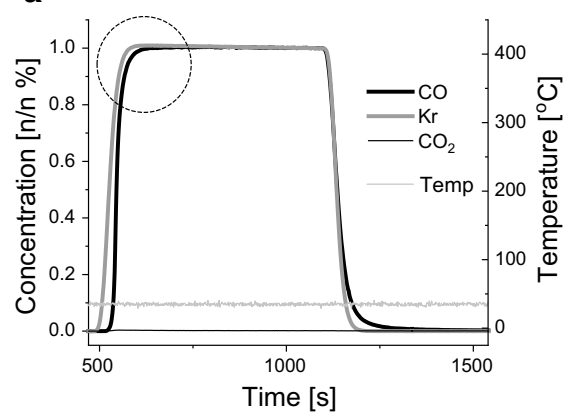

b

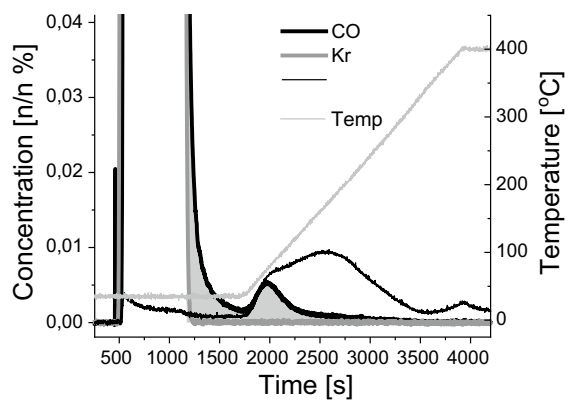

Fig. 4 Binary concentration pulse chromatography with mixed $1 \% \mathrm{CO}+1 \% \mathrm{Kr}$ pulses in $\mathrm{Ar}$ stream for determination of the amount of adsorbed $\mathrm{CO}$ on $\mathrm{Au} / \mathrm{Al}_{2} \mathrm{O}_{3}$ sample, with a possible $\mathrm{CO}+\mathrm{Au}_{\mathrm{n}} \mathrm{O} \rightarrow \mathrm{CO}_{2}+\mathrm{Au}_{\mathrm{n}}$ process (encircled, left, a), and the enlarged (ca. 25 times) bottom portion of the concentration jump on the left supplemented with the desorption in the subsequent TPD (right, b)

$\mathrm{Kr}$ in the Ar mixture at $35{ }^{\circ} \mathrm{C}$. The signal of $\mathrm{CO}$ is delayed in a certain extent as compared to the non-adsorbing $\mathrm{Kr}$. After $10 \mathrm{~min}$, having the sorption processes equilibrated the flow of $1+1 \% \mathrm{CO}+\mathrm{Kr}$ mixture is abruptly stopped, then the signal of $\mathrm{CO}$ related to that of $\mathrm{Kr}$ is delayed again. The delay in the ascending side is proportional to the amount of adsorbed $\mathrm{CO}$. There is a further lag in the $\mathrm{CO}$ signal at the beginning of top of the $\mathrm{Kr}+\mathrm{CO}$ pulse (encircled in the Fig. 4a), it may be partly related to a certain reduction of the $\mathrm{Au}_{\mathrm{n}} \mathrm{O}$ species formed in the in situ calcination prior to the exposure to the $\mathrm{CO}+\mathrm{Kr}$ pulse. Thus, the total amount of spent $\mathrm{CO}$ is added from contributions of $\mathrm{CO}_{\mathrm{ads}}$ and $\mathrm{CO}+\mathrm{Au}_{\mathrm{n} \text {,surf }} \mathrm{O} \rightarrow \mathrm{CO}_{2}+\mathrm{Au}_{\mathrm{n} \text {,surf }}$. The carbon dioxide formed can be fixed on the support depending on its basicity (see also in Fig. 1a). On the descending side, the delay of the CO signal appears only on the bottom part of the pulse, however it is tailing due to the slow desorption from gold. The desorption process can be facilitated with a TPD of CO as shown in Fig. 4b. Since the amount of the desorbed carbon monoxide in the descending step, $\mathrm{CO}_{\mathrm{des}}$, is exempt from other processes, it can be considered for the estimation of the amount of chemisorbed carbon monoxide. In correspondence with the mentioned $\mathrm{CO}_{2}$ formation, the MS signal of $\mathrm{CO}_{2}$ desorbing from the support could also be detected during the TPD, as shown in Fig. 4b. The adsorption of $\mathrm{CO}$ on pretreated bare supports was also determined. Its extent is much smaller than on supported gold catalysts, but it is not negligible. Thus, it was subtracted from that measured for the corresponding supported gold catalysts providing the $\mathrm{CO}$ amount adsorbed on $\mathrm{Au}$ sites. The amount of $\mathrm{CO}$ adsorption and desorption on gold related to $1 \mathrm{~mol} \mathrm{Au}$ content in the different samples are summarized in Table 4 and compared with the IR band intensities of $\mathrm{CO}$ adsorbed on the in situ calcined samples.

It is worth to notice that the correspondence between the data for the $\log (1 / \mathrm{R})$ band intensities of adsorbed CO obtained from the DRIFTS and binary concentration pulse chromatography methods is fairly good. Namely, the order of the catalysts from the point 
of view of the adsorbed $\mathrm{CO}$ is $\mathrm{Au} / \mathrm{Al}_{2} \mathrm{O}_{3}>\mathrm{Au} / \mathrm{MgAl}_{2} \mathrm{O}_{4}>\mathrm{Au} / \mathrm{SiO}_{2}>\mathrm{Au} / \mathrm{HAP}>\mathrm{Au} / \mathrm{MgO}$ by both of the methods.

A simple geometric approximation was used to estimate the number of surface gold atoms as mentioned in the beginning of the Results and Discussion chapter in connection with dispersion data presented in Table 2. In the knowledge of the quantitative amounts of adsorbed $\mathrm{CO}$ on gold the fractional coverage of gold nanoparticles can also be estimated by dividing the recent desorption data with the amount of surface Au atoms. The resulting data are shown in the last column of Table 4. In agreement with the expectations, the fractional coverages are in correlation with the mean particle sizes. Only the coordinatively unsaturated gold atoms on the surface of nanoparticles are able to adsorb $\mathrm{CO}$, their proportion is increasing with the decrease of the particle size. The largest fractional coverage is found for $\mathrm{Au} / \mathrm{Al}_{2} \mathrm{O}_{3}$ $(15 \%)$ in agreement with the smallest average particle size found for this catalyst $\left(\sim 1.7 \mathrm{~nm}\right.$, Table 2). The medium sizes on $\mathrm{SiO}_{2}, \mathrm{MgAl}_{2} \mathrm{O}_{4}$ and $\mathrm{HAP}(2.4,2.7$ and $2.7 \mathrm{~nm}$,) are reflected in medium fractional coverages in case of the two former support (7 and 8\%). Surprisingly, it is much lower on HAP (3\%). This latter value may be explained by the reverse SMSI effect on Au/HAP on calcination reported in [36]. Further on, particles with the largest $\mathrm{Au}$ size on $\mathrm{MgO}$ ( $6.5 \mathrm{~nm}$ mean diameter) exhibit similarly low fractional surface coverage (3\%) as found on HAP.

\section{Aerobic oxidation of benzyl alcohol in xylene solvent at $60^{\circ} \mathrm{C}$ in absence of $\mathrm{K}_{2} \mathrm{CO}_{3}$}

The initial reaction rates of $\mathrm{BzOH}$ conversions were determined from the slopes in the linear sections of the conversion-time diagrams (the first 3 points in Fig. 5a and c), similarly as for example in [14]. The order of the activity of gold catalysts on various supports in absence of $\mathrm{K}_{2} \mathrm{CO}_{3}$ is: $\mathrm{SiO}_{2}(\sim 0)<\mathrm{HAP}<\mathrm{MgO}<\mathrm{Al}_{2} \mathrm{O}_{3} \approx \mathrm{MgAl}_{2} \mathrm{O}_{4}$. In the initial stage of the reaction the spread of activities on the different catalysts is rather broad, the conversion is modest (uppermost 7\%) and in correspondence, the selectivity for $\mathrm{BzO}$ exceeds $95 \%$. The sole detectable side product is the ester, $\mathrm{BzO}-$ OBz. Thus, dominantly only reaction A has taken place (Scheme 1). The two important stages in this oxidation cycle are the deprotonation promoted by the support, and the $\beta$-hydride elimination taking place on the gold nanoparticles [7].

$\mathrm{GSNA}_{\text {ini }}$ and $\mathrm{ASNA}_{\text {ini }}$ values are calculated in Table 5 from initial reaction rates by considering the concentration of either surface $\mathrm{Au}$ atoms (Au concentration, $\mathrm{mol} / \mathrm{g}_{\mathrm{cat}}$ multiplied by dispersion) or active, $\mathrm{CO}$ adsorbing surface gold atoms (obtained from the last column of Table 4), respectively. As mentioned earlier, from the aspect of size dependence of benzyl-alcohol oxidation controversial reports can be found, namely either monotonous increase of TOF with the size reduction of gold $[9,14,15,29]$ or volcano type dependence with activity maximum at 6-9 $\mathrm{nm}$ Au sizes [19]. In the former case the comparison of $\mathrm{ASNA}_{\text {ini }}$ is the more reliable to compare the influence of different support. If the latter case is valid GSNA ${ }_{\text {ini }}$ values are in better contrast taking into account all the surface Au atoms. However, the joint effect of particle size and type of support cannot be separated, rather the comparison of the catalysts of the similar size Au particles gives reliable information on the support effect. From the aspect of further comparisons it is worth noticing that in most publications the reported TOF 

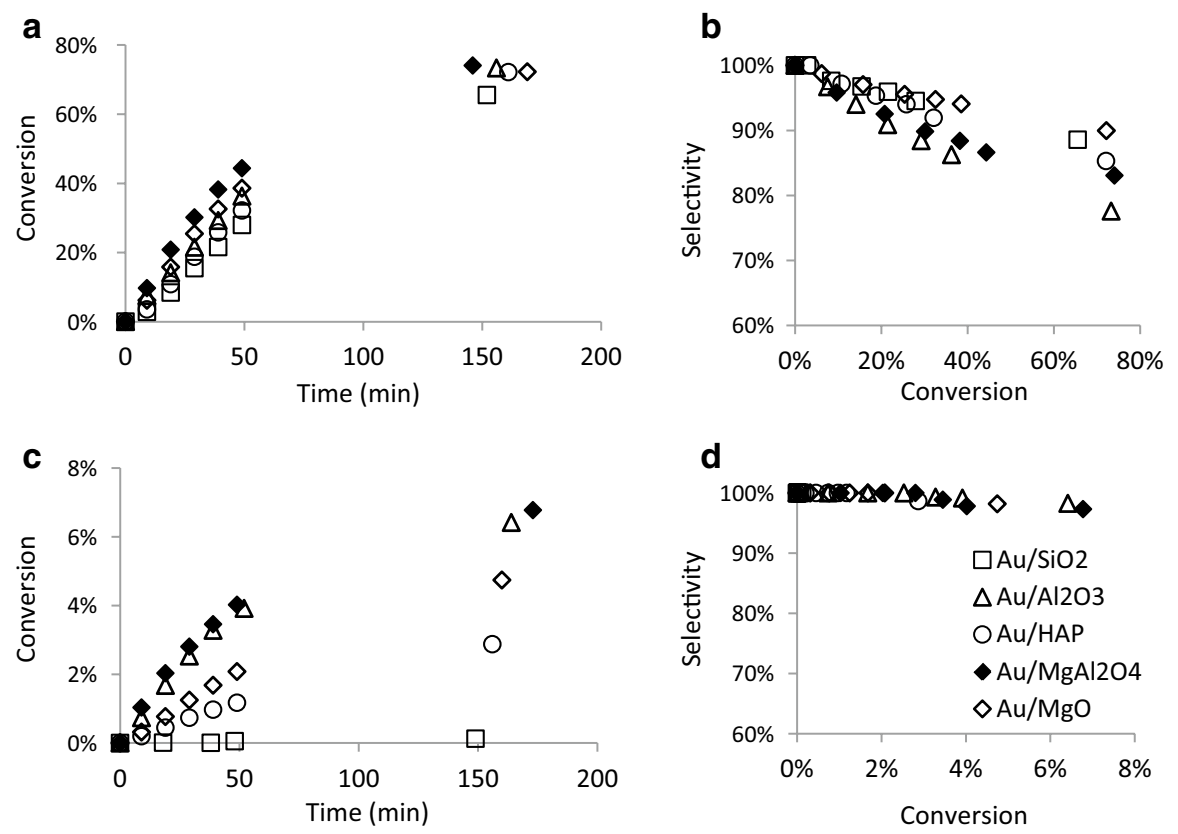

Fig. 5 Conversion versus reaction time (a, c, left) and selectivity versus conversion (b, $\mathbf{d}$, right) curves of benzyl alcohol oxidation on supported Au catalysts, in presence (a,b, top) and in absence (c, d, bottom) of $\mathrm{K}_{2} \mathrm{CO}_{3}$. (Note the different scales on the conversion axes.)

Table 5 Comparison of normalized conversion rates from measurements performed (i) at $60{ }^{\circ} \mathrm{C}$ in xylene solvent and (ii) $150{ }^{\circ} \mathrm{C}, 5$ bar $\mathrm{O}_{2}, 5 \mathrm{~h}$

\begin{tabular}{|c|c|c|c|c|c|}
\hline \multirow{3}{*}{$\begin{array}{l}\text { Conditions } \\
\text { Catalyst }\end{array}$} & \multicolumn{4}{|c|}{ (i) In xylene solvent, $60^{\circ} \mathrm{C}, 1$ bar $\mathrm{O}_{2}$} & \multirow{3}{*}{$\begin{array}{l}\text { (ii) Solvent-free, } 150{ }^{\circ} \mathrm{C}, 5 \mathrm{bar} \\
\mathrm{O}_{2} \\
\text { In absence of } \mathrm{K}_{2} \mathrm{CO}_{3} \\
\mathrm{GSNA}_{\text {ave }}^{\mathrm{a}} \mathrm{s}^{-1}\end{array}$} \\
\hline & \multicolumn{2}{|c|}{ In absence of $\mathrm{K}_{2} \mathrm{CO}_{3}$} & \multicolumn{2}{|c|}{ In presence of $\mathrm{K}_{2} \mathrm{CO}_{3}$} & \\
\hline & $\mathrm{GSNA}_{\text {ini }} \mathrm{s}^{-1}$ & $\mathrm{ASNA}_{\text {ini }} \mathrm{s}^{-1}$ & $\mathrm{GSNA}_{\text {ini }} \mathrm{s}^{-1}$ & $\mathrm{ASNA}_{\text {ini }} \mathrm{s}^{-1}$ & \\
\hline $\mathrm{Au} / \mathrm{SiO}_{2}$ & 0 & 0 & 0.28 & 3.97 & 0.63 \\
\hline $\mathrm{Au} / \mathrm{Al}_{2} \mathrm{O}_{3}$ & 0.04 & 0.28 & 0.36 & 2.41 & 0.16 \\
\hline $\mathrm{Au} / \mathrm{HAP}$ & 0.02 & 0.65 & 0.44 & 14.81 & 0.47 \\
\hline $\mathrm{Au} / \mathrm{MgAl}_{2} \mathrm{O}_{4}$ & 0.06 & 0.69 & 0.64 & 8.00 & 0.40 \\
\hline $\mathrm{Au} / \mathrm{MgO}$ & 0.05 & 1.56 & 1.22 & 40.8 & 0.83 \\
\hline
\end{tabular}

${ }^{\text {a }}$ These data are obtained from measurements with high conversions (see Table 6)

values are related either to all metal atoms or to all surface atoms, respectively, which may result in a certain ambiguity $[16,17]$.

The interpretation of catalytic processes taking place in absence of $\mathrm{K}_{2} \mathrm{CO}_{3}$ may primarily be related to the basicity and to the density of active sites on gold particles. In particular, silica is neutral, the starting activation of $\mathrm{BzOH}$ for the catalytic cycle probably does not take place, GSNA (and ASNA) are practically zero. HAP, 
the support of the next catalyst in the increasing order of activities, possesses the highest specific basicity (Table 1). However, from the aspect of the number of $\mathrm{Au}$ sites adsorbing $\mathrm{CO}$, as well as the accessible Au surface are surprisingly low, likely because of the supposed partial encapsulation of Au particles by HAP [36]. The balance of basicity and accessibility results probably in the modest GSNA $_{\text {ini }}$, but similar $\mathrm{ASNA}_{\text {ini }}$ as the most active $\mathrm{Au} / \mathrm{MgAl}_{2} \mathrm{O}_{4}$ of similar gold size. Alumina, the next support in the order of activities of catalysts, exhibits only small overall basicity. In the relatively good performance probably the smallest particle size with highest concentration of low coordinated sites plays important role $(1.7 \mathrm{~nm}$, Table 2$)$. The better performance of the $\mathrm{Au} / \mathrm{MgO}$ catalyst can probably be related to the better specific basicity of the support (Table 1). The best $\mathrm{GSNA}_{\text {ini }}$ is found on $\mathrm{MgAl}_{2} \mathrm{O}_{4}$, its specific basicity is similar to that of $\mathrm{MgO}$, connected to higher surface density. From the point of view of $\mathrm{ASNA}_{\text {ini }} \mathrm{Au} / \mathrm{MgO}$ is the most active by far (due to the large particle size with less low coordinated sites).

\section{Aerobic oxidation of benzyl alcohol in xylene solvent at $60^{\circ} \mathrm{C}$ in presence of $\mathrm{K}_{2} \mathrm{CO}_{3}$}

As expected, addition of $\mathrm{K}_{2} \mathrm{CO}_{3}$ to the reaction mixture in stoichiometric amount results in a 10-20 fold increase in the conversion rates compared to those found in absence of $\mathrm{K}_{2} \mathrm{CO}_{3}$ since the added base increases the deprotonation of $\mathrm{BzOH}$ [8] and eliminates the poisoning effect of the $\mathrm{BzOOH}$ [7]. The apparent conversion rates are rather similar to each other in the $\mathrm{SiO}_{2}<\mathrm{HAP}<\mathrm{Al}_{2} \mathrm{O}_{3}<\mathrm{MgO}<\mathrm{MgAl}_{2} \mathrm{O}_{4}$ increasing order (Fig. 5a). The extents of conversions during $3 \mathrm{~h}$ exceed $60 \%$ in all cases, the corresponding $\mathrm{BzO}$ selectivities fall into the $77-90 \%$ range, thus formation of $\mathrm{BzOOBz}$ has also taken place in modest extent rather via reaction $\mathrm{D}$ (due to base addition $\mathrm{B}+\mathrm{C}$ route is less probable in Scheme 1 [7]). The $\mathrm{BzOOBz}$ selectivity increases with increasing acidity of the supports.

After having the $\mathrm{Au}$ dispersions taken into account the differences between the GSNA $_{\text {ini }}$ values are maximum ca. 4.5 fold, their order is $\mathrm{SiO}_{2}<\mathrm{Al}_{2} \mathrm{O}_{3}<\mathrm{HAP}<\mathrm{MgAl}_{2} \mathrm{O}_{4}<\mathrm{MgO}$ (Table 5). In the later stage, considering only the extent of the reactive surface gold atoms, the previous order of activities changes, the difference between the smallest and largest activities ( $\left.\mathrm{ASNA}_{\text {ini }}\right)$ exceeds even an order of magnitude. In the case of reactions performed with $\mathrm{K}_{2} \mathrm{CO}_{3}$ addition, the role of basicity of supports is less expressed, the acidity of supports should also be considered and probably the balance of the acidic versus basic strengths is also an important parameter. In agreement, $\mathrm{Au} / \mathrm{SiO}_{2}$ and $\mathrm{Au} / \mathrm{Al}_{2} \mathrm{O}_{3}$ are the least active with respect to both $\mathrm{GSNA}_{\text {ini }}$ and $\mathrm{ASNA}_{\text {ini }}$. Alumina support exhibits strong acidic sites (Fig. 1b). Furthermore, it should be added that the average gold particle size on this catalyst is the smallest $(1.7 \mathrm{~nm})$, maybe the number of neighboring Au sites is already insufficient for the appropriate $\mathrm{BzOH}$ adsorption resulting in a drop of activity as observed in [14]. $\mathrm{SiO}_{2}$ is neutral, being neither acidic nor basic (Fig. 1), thus the activity of $\mathrm{Au} / \mathrm{SiO}_{2}$ catalyst can be considered as the one originated primarily from the gold nanoparticles with only minor influence of the support. The next more active catalyst is $\mathrm{Au} / \mathrm{MgAl}_{2} \mathrm{O}_{4}$ or $\mathrm{Au} / \mathrm{HAP}$ according to $\mathrm{GSNA}_{\text {ini }}$ and $\mathrm{ASNA}_{\text {ini }}$, respectively. However, Au/HAP can be regarded to be better since its $\mathrm{GSNA}_{\text {ini }}$ is 
underestimated as not all surface $\mathrm{Au}$ is accessible. $\mathrm{MgAl}_{2} \mathrm{O}_{4}$ has the largest acidity and the second largest basicity, for HAP the opposite is observed. Thus, the activity of gold might be better on these supports than on alumina and silica. The activity of $\mathrm{Au} / \mathrm{MgO}$ is the best, its $\mathrm{GSNA}_{\text {ini }}$ and $\mathrm{ASNA}_{\text {ini }}$ values outperform those of all the other catalysts by ca. 2-4 and 5-10 times, respectively. $\mathrm{MgO}$ principally a basic support, the size range of gold particles on it is the same as was found to be the most active in Haider et al.'s $[19,48]$ reports, too.

Additionally, it should be emphasized that water as by product is formed in significant amount in the reaction at large conversions (e.g. $60 \%$ conversion may result in formation of $20-25 \mathrm{mg}$ water which strongly exceeds the mass of $15 \mathrm{mg}$ catalyst present in the reaction mixture). Thus, for the deeper interpretation of the promoting effect of $\mathrm{K}_{2} \mathrm{CO}_{3}$, the promoting effect of the water should also be considered (discussed in more detail later).

\section{Solvent-free oxidation of benzyl alcohol in autoclave under 5 bar $\mathrm{O}_{2}$ at $150^{\circ} \mathrm{C}$}

The oxidation of the $\mathrm{BzOH}$ substrate under these conditions was carried on for $5 \mathrm{~h}$. The extents of conversions of $\mathrm{BzOH}$ and the selectivities of products are collected in Table 6, the corresponding acid-base properties, conversions and yields of various products are illustrated in Fig. 6.

The reaction conditions applied in solvent-free media with 5 bar starting load of oxygen at $150{ }^{\circ} \mathrm{C}$ were distinctly different from those of the atmospheric experiments carried out in xylene solvent without $\mathrm{K}_{2} \mathrm{CO}_{3}$ additive. Almost complete (>85\%) conversions were observed (except $\mathrm{Au} / \mathrm{Al}_{2} \mathrm{O}_{3}$ with only 47\%). The starting amount of oxygen provided by the 5 bar load had been depleted almost completely in the reaction with the $2 \mathrm{ml} \mathrm{BzOH}$ substrate at these high conversions. Thus, the yields shown in Fig. 6 can be considered as corresponding to occasional equilibria established in the available pool of components.

Further on, it should be noticed that presence of the other reaction product, water, may also play a significant role. Namely, it promotes selectively the formation of $\mathrm{BzOOH}$ from $\mathrm{BzO}$ [5]. Considering ca. $80 \%$ conversion in average, presence of ca. $20 \mathrm{mmol}(360 \mathrm{mg}$ ) water can be expected at the final stage, which is a large excess compared to the used $50 \mathrm{mg}$ supported catalyst. The differences in the observed yields of products can probably be attributed to the different extents of completion

Table 6 Conversions and selectivities of $\mathrm{BzOH}$ oxidation (solvent-free, 5 bar $\mathrm{O}_{2}, 150{ }^{\circ} \mathrm{C}$, $5 \mathrm{~h}$ )

\begin{tabular}{lllll}
\hline Catalyst & $\begin{array}{l}\text { Conversion of } \\
\text { BzOH }(\%)\end{array}$ & \multicolumn{3}{l}{ Selectivity (\%) } \\
\cline { 3 - 5 } & & $\mathrm{BzO}$ & $\mathrm{BzOOH}$ & $\mathrm{BzOOBz}$ \\
\hline $\mathrm{Au} / \mathrm{MgO}$ & 85 & 47 & 29 & 24 \\
$\mathrm{Au} / \mathrm{MgAl}_{2} \mathrm{O}_{4}$ & 94 & 31 & 21 & 48 \\
$\mathrm{Au} / \mathrm{HAP}$ & 87 & 66 & 14 & 20 \\
$\mathrm{Au} / \mathrm{Al}_{2} \mathrm{O}_{3}$ & 47 & 93 & 6 & 1 \\
$\mathrm{Au} / \mathrm{SiO}_{2}^{\mathrm{a}}$ & 91 & 29 & 56 & 15 \\
\hline
\end{tabular}

${ }^{\mathrm{a}} 1.8 \mathrm{wt} \% \mathrm{Au}$ 

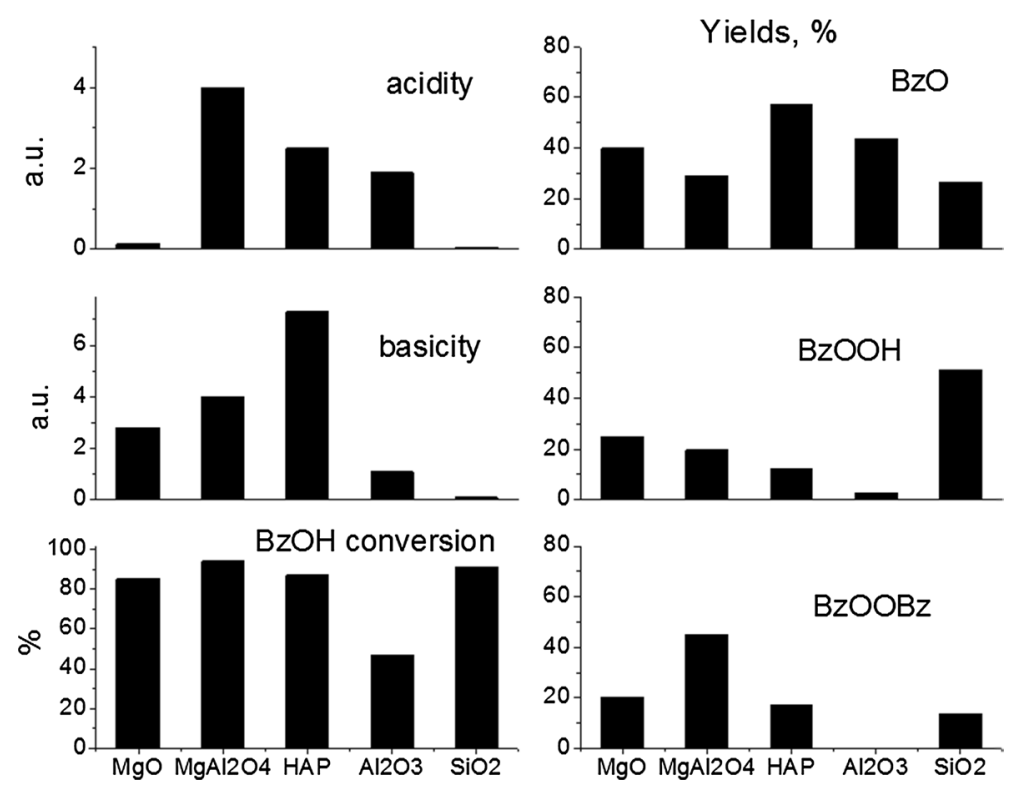

Fig. 6 Overall acidity and basicity (a.u.) of supports and detected conversions of $\mathrm{BzOH}$ (left) and yields of formation of $\mathrm{BzO}, \mathrm{BzOOH}$ and $\mathrm{BzOOBz}$ (right) on various samples in solvent-free conditions after $5 \mathrm{~h}$ reaction at $150{ }^{\circ} \mathrm{C}$ with 5 bar $\mathrm{O}_{2}$ load

of processes shown in Scheme 1, due to the various acid-base properties and to the extents of water present on the support during reactions.

\section{Comparison of the activities determined under different experimental conditions}

The activities determined under the different experimental conditions can be compared in Table 5. However, a comparison of GSNA $_{\text {ini }}$ in the case of measurements

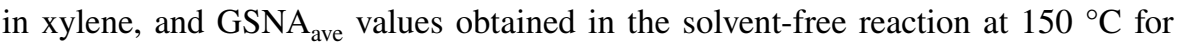
$5 \mathrm{~h}$ needs precaution since the conversions in these latter tests were high, the proportional conversion-reaction time range of reactions had already been passed over. Furthermore, deactivation might have been taken place [49], so these values are probably underestimated as compared to a corresponding GSNA $_{\text {ini }}$.

Recent results obtained under the solvent-free conditions are valuable from practical aspects, providing a guide for practical applications. Selectivities at close to total conversion are worth also to compare. However further detailed investigation of the kinetics and mechanism is needed for better understanding the markedly different performances.

A comparison of our catalysts with literature ones in solvent-free conditions is presented in Table 7. The activities are characterized by the average rate of $\mathrm{BzOH}$ conversion during reaction time given related to $1 \mathrm{~mol} \mathrm{Au}$ atoms (both surface and bulk) as mostly used (as TOF) in the cited papers. It should be noted that greater number of supports are compared in the report of Choudhary et al. [50], the 
Table 7 Comparison of performance of various catalysts in solvent-free oxidation of benzaldehyde

\begin{tabular}{|c|c|c|c|c|c|c|c|c|}
\hline Catalyst & $\begin{array}{l}\text { Au particle } \\
\text { size } \\
(\mathrm{nm})\end{array}$ & $\left({ }^{\circ} \mathrm{C}\right)$ & (MPa) & Time & Conversion & Selectivity $^{\mathrm{a}}$ & $\begin{array}{l}\text { Activity } \\
\mathrm{mol}_{\mathrm{BzOH}} / \mathrm{h} / \\
\mathrm{mol}_{\mathrm{Au}} \\
\left(\mathrm{h}^{-1}\right)\end{array}$ & Ref. \\
\hline $\mathrm{Au} / \mathrm{Al}_{2} \mathrm{O}_{3}$ & $1.7 \pm 0.8$ & 150 & 0.5 & 5 & 47 & 93 & 247 & This work \\
\hline $\mathrm{Au} / \mathrm{MgO}$ & $6.5 \pm 2.1$ & 150 & 0.5 & 5 & 85 & 47 & 446 & This work \\
\hline $\mathrm{Au} / \mathrm{HAP}$ & $2.7 \pm 1.3$ & 150 & 0.5 & 5 & 87 & 66 & 457 & This work \\
\hline $\begin{array}{l}\mathrm{Au} / \\
\mathrm{MgAl}_{2} \mathrm{O}_{4}\end{array}$ & $2.7 \pm 1.1$ & 150 & 0.5 & 5 & 94 & 31 & 494 & This work \\
\hline $\mathrm{Au} / \mathrm{SiO}_{2}$ & $2.4 \pm 0.9$ & 150 & 0.5 & 5 & 91 & 29 & 797 & This work \\
\hline $\begin{array}{c}\mathrm{Au} / \mathrm{CeO}_{2^{-}} \\
\mathrm{RRCe}\end{array}$ & 4.5 & 150 & 0.5 & 8 & 37 & 72 & 288 & [31] \\
\hline $\mathrm{Au} / \mathrm{CeO}_{2}$ & n.a. & 100 & 0.2 & 3 & 3.4 & 100 & 215 & [49] \\
\hline $\mathrm{Au} / \mathrm{SiO}_{2}$ & n.a. & 100 & 0.2 & 3 & 1.9 & 100 & 343 & [49] \\
\hline $\mathrm{Au} / \mathrm{SiO}_{2}$ & n.a. & 100 & 0.6 & 3 & 4.7 & 92 & 848 & [49] \\
\hline $\mathrm{Au} / \mathrm{ZrO}_{2}$ & $4.5 \pm 1.2$ & 130 & 0.15 & 5 & 51 & 87 & 192 & [50] \\
\hline $\mathrm{Au} / \mathrm{Al}_{2} \mathrm{O}_{3}$ & $3.6 \pm 1.1$ & 130 & 0.15 & 5 & 69 & 65 & 125 & [50] \\
\hline $\mathrm{Au} / \mathrm{MgO}$ & $8.9 \pm 0.7$ & 130 & 0.15 & 5 & 51 & 86 & 81 & [50] \\
\hline $\mathrm{Au} / \mathrm{MgO}$ & 9 & 120 & 0.1 & 5 & 56 & 95 & 88 & [28] \\
\hline $\begin{array}{c}\mathrm{Fe}_{3} \mathrm{O}_{4} / \mathrm{Au} / \\
\mathrm{SiO}_{2}\end{array}$ & 11 & 140 & 0.1 & 4 & 49 & 97 & 71 & [51] \\
\hline
\end{tabular}

${ }^{\text {a }}$ Selectivity of benzaldehyde

activities scatter between 30 and $192(\mathrm{~mol} \mathrm{BnOH} / \mathrm{h} / \mathrm{mol} \mathrm{Au})$. Our catalysts exhibit rather good performance in oxidation of $\mathrm{BzOH}$. The good activities are probably connected to the stabilization of gold particles in small size range. The selectivities to benzaldehyde on our samples at $85 \%$ or higher conversions are significantly smaller in comparison to other catalysts in Table 7, where the extents of $\mathrm{BzOH}$ conversions were much lower.

\section{Summary}

Monodisperse PVA stabilized gold particles of around $2 \mathrm{~nm}$ diameter were prepared and adsorbed on non-redox supports of various acid-base properties, namely on $\mathrm{SiO}_{2}, \mathrm{Al}_{2} \mathrm{O}_{3}, \mathrm{MgO}, \mathrm{MgAl}_{2} \mathrm{O}_{4}$ and $\mathrm{HAP}$. The next activation with calcination at $400{ }^{\circ} \mathrm{C}$ results in sintering of gold in different extents. The samples were characterized by TEM, CO adsorption followed by DRIFTS and measured by binary concentration pulse chromatography. The basicity and acidity of the supports were probed by $\mathrm{CO}_{2}$ - and $\mathrm{NH}_{3}-\mathrm{TPD}$, respectively.

Catalytic benzyl alcohol oxidation tests were performed under three experimental conditions. In the first and second version the reaction was carried out in xylene solvent at atmospheric pressure of oxygen at $60{ }^{\circ} \mathrm{C}$, either in presence or in absence of $\mathrm{K}_{2} \mathrm{CO}_{3}$ in stoichiometric amount. Conversion and selectivity were determined in 
dependence of reaction time. In the third version the reaction was carried out in solvent-free condition, under 5 bar $\mathrm{O}_{2}$ starting pressure at $150{ }^{\circ} \mathrm{C}$, the conversion and selectivity were measured after $5 \mathrm{~h}$ reaction. In the first and second case the activities of catalysts were derived from initial conversion rates related either to the number of gold atoms located on the geometric surface of particles $\left(\mathrm{GSNA}_{\mathrm{ini}}\right)$ or to the number of active surface sites ( $\mathrm{ASNA}_{\mathrm{ini}}$ ). The latter number of the active sites on gold particles was determined from $\mathrm{CO}$ adsorption followed by binary concentration pulse chromatography. In the third version of experimental conditions, the average reaction rates for the $5 \mathrm{~h}$ reaction were determined and were related to the respective amounts of surface gold atoms (GSNA ${ }_{\text {ave }}$ ). In xylene solution in the absence of $\mathrm{K}_{2} \mathrm{CO}_{3}$, the activities of catalysts were characterized with $0-0.06$ and $0-1.56 \mathrm{~s}^{-1}, \mathrm{GSNA}_{\text {ini }}$ and $\mathrm{ASNA}_{\text {ini }}$ respectively. The catalysts deactivated below $10 \%$ conversion. The addition of $\mathrm{K}_{2} \mathrm{CO}_{3}$ resulted in a significant activity increase as reflected by $0.28-1.22$ and 2.41-40.8 s ${ }^{-1}$ GSNA $_{\text {ini }}$ and ASNA $_{\text {ini }}$ values. The BzO selectivity was above $75 \%$ at around $70 \%$ conversion. The observed order of $\mathrm{GSNA}_{\text {ini }}$ values under base free conditions is $\mathrm{Au} / \mathrm{SiO}_{2}(\approx 0)<\mathrm{Au} / \mathrm{HAP}<\mathrm{Au} / \mathrm{Al}_{2} \mathrm{O}_{3}<\mathrm{Au} / \mathrm{MgO}<\mathrm{Au} / \mathrm{MgAl}_{2} \mathrm{O}_{4}$, and in presence of $\mathrm{K}_{2} \mathrm{CO}_{3}$ is $\mathrm{Au} / \mathrm{SiO}_{2}<\mathrm{Au} / \mathrm{Al}_{2} \mathrm{O}_{3}<\mathrm{Au} / \mathrm{HAP}<\mathrm{Au} / \mathrm{MgAl}_{2} \mathrm{O}_{4}<\mathrm{Au} / \mathrm{MgO}$. In the solvent-free experiments performed at $150{ }^{\circ} \mathrm{C}$ only the less exact average GSNA $_{\text {ave }}$ values after $5 \mathrm{~h}$ reaction were determined, which ranged between 0.16 and $0.83 \mathrm{~s}^{-1}\left(\mathrm{Au} / \mathrm{Al}_{2} \mathrm{O}_{3}<\mathrm{Au} / \mathrm{MgAl}_{2} \mathrm{O}_{4}<\mathrm{Au} / \mathrm{HAP}<\mathrm{Au} / \mathrm{MgO}<\mathrm{Au} / \mathrm{SiO}_{2}\right)$, however quite high conversions, $>85 \%$ (with the exception of $\mathrm{Au} / \mathrm{Al}_{2} \mathrm{O}_{3}, 47 \%$ ) were reached. The selectivities of the various samples are very different.

As demonstrated, for the interpretation of the obtained data the roles of active sites on gold nanoparticles of various dispersion, accessibility of the gold surface and the differing surface partial charge on gold, as well as the acid-base properties of various supports should be considered simultaneously in various extents depending the reaction conditions applied. Promoting role of water formed in the reaction with generation of surface hydroxyl groups is probably also important.

Acknowledgements Open access funding provided by MTA Wigner Research Centre for Physics (MTA Wigner FK, MTA EK). The authors are thankful to Ágnes Szegedi for the determination of the specific surface area of the HAP support. The financial support obtained for the Hungarian-Chinese bilateral cooperation in Project TET_15-1-2016-0120 is thankfully acknowledged.

Open Access This article is distributed under the terms of the Creative Commons Attribution 4.0 International License (http://creativecommons.org/licenses/by/4.0/), which permits unrestricted use, distribution, and reproduction in any medium, provided you give appropriate credit to the original author(s) and the source, provide a link to the Creative Commons license, and indicate if changes were made.

\section{References}

1. Ma Z, Dai S (eds) (2014) Heterogeneous gold catalysts and catalysis. RSC catalysis series. $592 \mathrm{pp}$

2. Haruta M (2011) Spiers memorial lecture: role of perimeter interfaces in catalysis by gold nanoparticles. Faraday Discuss 152:11-32

3. Abad A, Corma A, Garcia H (2008) Catalyst parameters determining activity and selectivity of supported gold nanoparticles for the aerobic oxidation of alcohols: the molecular reaction mechanism. Chem Eur J 14:212-222 
4. Ferraz CP, Garcia MAS, Teixeira-Neto É, Rossi LM (2016) Oxidation of benzyl alcohol catalysed by gold nanoparticles under alkaline conditions: weak vs. strong bases. RSC Adv 6:25279

5. Kumar R, Gravel E, Hagège A, Li H, Jawale DV, Verma D, Namboothiri INN, Doris E (2013) Carbon nanotube-gold nanohybrids for selective catalytic oxidation of alcohols. Nanoscale 5:6491

6. Castro KPR, Garcia MA, de Abreu WC, de Sousa SAA, de Moura CVR, Costa JCS, de Moura EM (2018) Aerobic oxidation of benzyl alcohol on a strontium-based gold material: remarkable intrinsic basicity and reusable catalyst. Catalysts 8:83

7. Skupien E, Berger RJ, Santos VP, Gascon J, Makkee M, Kreutzer MT, Kooyman PJ, Moulijn JA, Kapteijn F (2014) Inhibition of a gold-based catalyst in benzyl alcohol oxidation: understanding and remediation. Catalysts 4:89-115

8. Malláth T, Baiker A (2004) Oxidation of alcohols with molecular oxygen on solid catalysts. Chem Rev 104:3037-3058

9. Fang W, Chen J, Zhang Q, Deng W, Wang Y (2011) Hydrotalcite-supported gold catalyst for the oxidant-free dehydrogenation of benzyl alcohol: studies on support and gold size effects. Chem Eur J 17:1247-1256

10. Zope BN, Hibbitts DD, Neurock M, Davis RJ (2010) Reactivity of the gold/water interface during selective oxidation catalysis. Science 330:74-78

11. Sankar M, Nowicka E, Tiruvalam R, He Q, Taylor SH, Kiely CJ, Bethell D, Knight DW, Hutchings GJ (2011) Controlling the duality of the mechanism in liquid-phase oxidation of benzyl alcohol catalysed by supported Au-Pd nanoparticles. Chem Eur J 17:6524-6532

12. Feng J, Ma C, Miedziak PJ, Edwards JK, Brett GL, Li D, Du Y, Morgan DJ, Hutchings GJ (2013) $\mathrm{Au}-\mathrm{Pd}$ nanoalloys supported on $\mathrm{Mg}-\mathrm{Al}$ mixed metal oxides as multifunctional catalyst fro solventfree oxydation of benzyl alcohol. Dalton Trans 42:14498

13. Galvanin F, Sankar M, Cattaneo S, Bethell D, Dua V, Hutchings GJ, Gavriilidis A (2018) On the development of kinetic models for solvent-free benzyl alcohol oxidation over a gold-palladium catalyst. Chem Eng J 342:196-210

14. Boronat M, Corma A, Illas F, Radilla J, Ródenas T, Sabater MJ (2011) Mechanism of selective alcohol oxidation to aldehydes on gold catalysts: influence of surface roughness on reactivity. J Catal 278:50-58

15. Tsunoyama H, Sakurai H, Tsukuda T (2006) Size effects on the catalysis of gold clusters dispersed in water for aerobic oxidation of alcohol. Chem Phys Lett 429:528-532

16. Kozuch S, Martin ML (2012) "Turning over" definitions in catalytic cycles. ACS Catal 2:2787-2794

17. Bligaard T, Bullock RM, Campbell CT, Chen JG, Gates BC, Gorte RJ, Jones CW, Jones WD, Kitchin JR, Scott SL (2016) Toward benchmarking in catalysis science: best practices, challenges and opportunities. ACS Catal 6:2590-2602

18. Lente G (2013) Comment on "Turning over definitions in catalytic cycles". ACS Catal 3:381-382

19. Haider P, Kimmerle B, Krumeich F, Kleist W, Grunwaldt J-D, Baiker A (2008) Gold-catalyzed aerobic oxidation of benzyl alcohol: effect of gold particle size on activity and selectivity in different solvents. Catal Lett 125:169-176

20. Guan Y, Hensen EJM (2009) Ethanol dehydrogenation by gold catalysts: the effect of the gold particle size and the presence of oxygen. Appl Catal A 361:49-56

21. Centeno MA, Hadjiivanov K, Tz Venkov, Hr Klimev, Odriozola JA (2006) Comparative study of $\mathrm{Au} / \mathrm{Al}_{2} \mathrm{O}_{3}$ and $\mathrm{Au} / \mathrm{CeO}_{2}-\mathrm{Al}_{2} \mathrm{O}_{3}$ catalysts. J Mol Catal A 252:142-149

22. Kennedy D, Tezel FH (2014) Improved method for determining binary adsorption isotherms by using concentration pulse chromatography: adsorption of $\mathrm{CO}_{2}$ and $\mathrm{N}_{2}$ by silicalite at different pressures. Adsorption 20:189-199

23. Shirani B, Eic M (2017) Novel differential column method for measuring multicomponent gas adsorption isotherms in NaY zeolite. Ind Eng Chem Res 56:1008-1018

24. Nagy G, Benkó T, Borkó L, Csay T, Horváth A, Frey K, Beck A (2015) Bimetallic Au-Ag/SiO 2 catalysts: comparison in glucose, benzyl alcohol and $\mathrm{CO}$ oxidation reactions. Reac Kinet Mech Cat 115:45-65

25. Li W, Wang A, Liu X, Zhang T (2012) Silica-supported Au-Cu alloy nanoparticles as an efficient catalyst for selective oxidation of alcohols. Appl Catal A 433-434:146-151

26. Rodriguez-Reyes JCF, Friend CM, Madix RJ (2012) Origin of the selectivity in the gold-mediated oxidation of benzyl alcohol. Surf Sci 606:1129-1134

27. Berndt H, Pitsch I, Evert S, Struve K, Pohl M-M, Radnik J, Martin A (2003) Oxygen adsorption on $\mathrm{Au} / \mathrm{Al}_{2} \mathrm{O}_{3}$ catalysts and relation to the catalytic oxidation of ethylene glycol to glycolic acid. Appl Catal A 244:169-179 
28. Choudhary VR, Dumbre DK (2011) Solvent-free oxidation of primary alcohols-to-aldehydes and aldehydes-to-carboxylic acids by molecular oxygen over $\mathrm{MgO}$ supported nano-gold catalyst. Catal Commun 13:82-86

29. Mitsudome T, Noujima A, Mizugaki T, Jitsukawa K, Kaneda K (2009) Efficient aerobic oxidation of alcohols using a hydrotalcite-supported gold nanoparticle catalyst. Adv Synth Catal 351:1890-1896

30. Choudhary VR, Dumbre DK (2009) Supported nano-gold catalysts for epoxidation of styrene and oxidation of benzyl alcohol to benzaldehyde. Top Catal 52:1677-1687

31. Li T, Liu F, Tang Y, Li L, Miao S, Su Y, Zhang J, Huang J, Sun H, Haruta M, Wang A, Qiao B, Li J, Zhang T (2018) Maximizing interfacial sites by single atom catalyst for solvent-free selective oxidation of primary alcohol. Angew Chem Int Ed 57:7795-7799

32. Abad A, Concepción P, Corma A, Garcia H (2005) A collaborative effect between gold and support induces the selective oxidation of alcohols. Angew Chem Int Ed 44:4066-4069

33. Li G, Enache DI, Edwards J, Carley AF, Knight DW, Hutchings GJ (2006) Solvent-free oxidation of benzyl alcohol with oxygen using zeolite-supported $\mathrm{Au}$ and $\mathrm{Au}-\mathrm{Pd}$ catalysts. Catal Lett 110:7-13

34. Fu X, Ding Z, Zhang X, Weng W, Xu Y, Liao J, Xie Z (2014) Preparation of halloysite nanotubesupported gold nanocomposite for solvent-free oxidation of benzyl alcohol. Nanosc Res Lett 9:282

35. Villa A, Gaiassi A, Rossetti I, Bianchi CL, van Benthem K, Veith GM, Prati L (2010) Au on $\mathrm{MgAl}_{2} \mathrm{O}_{4}$ spinels: the effect of support surface properties in glycerol oxidation. J Catal 275:108-116

36. Tang H, Wei J, Liu F, Qiao B, Pan X, Li L, Liu J, Wang J, Zhang T (2015) Strong metal-support interactions between gold nanoparticles and nonoxides. J Am Chem Soc 138:56-59

37. Beck A, Horvath A, Stefler G, Katona R, Geszti O, Tolnai G, Liotta LF, Guczi L (2008) Formation and structure of $\mathrm{Au} / \mathrm{TiO}_{2}$ and $\mathrm{Au} / \mathrm{CeO}_{2}$ in mesoporous SBA-15. Catal Today 139:180-187

38. Prati L, Villa A (2012) The art of manufacturing gold catalysts. Catalysts 2:24-37

39. Jouve A, Nagy G, Somodi F, Tiozzo C, Villa A, Balerna A, Beck A, Evangelisti C, Prati L (2018) Gold-silver catalysts: effect of catalyst structure on the selectivity of glycerol oxidation. J Catal 368:324-335

40. Zhong C, Guo X, Mao D, Wang S, Wu G, Lu G (2015) Effects of alkaline-earth oxides on the performance of a CuO- $\mathrm{ZrO}_{2}$ catalyst for methanol synthesis via $\mathrm{CO}_{2}$ hydrogenation. RSC Adv 5:52958

41. Diez VK, Apesteguia CR, Di Cosimo JI (2000) Acid-base properties and active site requirements for elimination reactions on alkali-promoted $\mathrm{MgO}$ catalysts. Catal Today 63:53-62

42. Pan Z, Zhao CY (2015) Dehydration/hydration of $\mathrm{MgO} / \mathrm{H}_{2} \mathrm{O}$ chemical thermal storage system. Energy 82:611-618

43. Anderson JR (1975) Structure of metallic catalysts. Academic Press, Cambridge

44. Li H, Li L, Pedersen A, Gao Y, Khetrapal N, Jónsson H, Zeng XC (2015) Magic-number gold nanoclusters with diameters from 1 to $3.5 \mathrm{~nm}$ : relative stability and catalytic activity for $\mathrm{CO}$ oxidation. Nano Lett 15:682-688

45. Hadjiivanov KI, Vayssilov GN (2002) Characterization of oxide surfaces and zeolites by carbon monoxide as an IR probe molecule. Adv Catal 47:307-511

46. Hr Klimev, Fajerwerg K, Chakarova K, Delannoy L, Louis C, Hadjiivanov K (2007) Oxidation of gold metal particles supported on $\mathrm{TiO}_{2}$ : an FTIR study by means of low-temperature $\mathrm{CO}$ adsorption. J Mater Sci 42:3299-3306

47. Yang K, Liu J, Si R, Chen X, Dai W, Fu X (2014) Comparative study of $\mathrm{Au} / \mathrm{TiO}_{2}$ and $\mathrm{Au} / \mathrm{Al}_{2} \mathrm{O}_{3}$ for oxidizing $\mathrm{CO}$ in the presence of $\mathrm{H}_{2}$ under visible light irradiation. J Catal 317:229-239

48. Haider P, Urakawa A, Schmidt E, Baiker A (2009) Selective blocking of active sites on supported gold catalysts by adsorbed thiols and its effect on the catalytic behavior: a combined experimental and theoretical study. J Mol Catal A 305:161-169

49. Enache DI, Knight DW, Hutchings GJ (2005) Solvent-free oxidation of primary alcohols to aldehydes using supported gold catalysts. Catal Lett 103:43-52

50. Choudhary VR, Dhar A, Jana P, Jha R, Uphade BS (2005) A green process for chlorine-free benzaldehyde from the solvent-free oxidation of benzyl alcohol with molecular oxygen over a supported nano-size gold catalyst. Green Chem 7:768-770 
51. Kokate M, Dapurkar S, Garadkar K, Gole A (2015) Magnetite-silica-gold nanocomposite: one-pot single-step synthesis and its application for solvent-free oxidation of benzyl alcohol. J Phys Chem C 119:14214-14223

Publisher's Note Springer Nature remains neutral with regard to jurisdictional claims in published maps and institutional affiliations.

\section{Affiliations}

Gergely Nagy ${ }^{1}$ - Andrea Beck ${ }^{1} \cdot$ György Sáfrán ${ }^{2} \cdot$ Zoltán Schay $^{1}$. Shaofeng Liu ${ }^{3,4} \cdot$ Tianbo $\mathrm{Li}^{3} \cdot$ Botao Qiao $^{3}$. Junhu Wang ${ }^{3,4} \cdot$ Károly Lázár $^{5}$

\section{Károly Lázár}

lazar.karoly@energia.mta.hu

1 Department of Surface Chemistry and Catalysis, Centre for Energy Research, HAS, Konkoly Thege M. út 29-33, Budapest 1121, Hungary

2 Laboratory of Thin Layer Physics, Institute of Materials Science, Centre for Energy Research, HAS, Konkoly Thege M. út 29-33, Budapest 1121, Hungary

3 State Key Laboratory of Catalysis, Dalian Institute of Chemical Physics, Chinese Academy of Sciences, 457 Zhongshan Road, Dalian 116023, China

4 Mössbauer Effect Data Center, Dalian Institute of Chemical Physics, Chinese Academy of Sciences, 457 Zhongshan Road, Dalian 116023, China

5 Department of Nuclear Analysis and Radiography, Centre for Energy Research, HAS, Konkoly Thege M. út 29-33, Budapest 1121, Hungary 